\title{
Interplay between Regulatory RNAs and Signal Transduction Systems during Bacterial Infection
}

\author{
Emma Piattelli ${ }^{1}$, Johann Peltier ${ }^{1,2}$ and Olga Soutourina ${ }^{1,3, *(D)}$ \\ 1 Institute for Integrative Biology of the Cell (I2BC), CNRS, CEA, Université Paris-Saclay, \\ 91198 Gif-sur-Yvette, France; emma.piattelli@i2bc.paris-saclay.fr (E.P.); johann.peltier@i2bc.paris-saclay.fr (J.P.) \\ 2 Laboratoire Pathogenèses des Bactéries Anaérobies, Institut Pasteur, UMR CNRS 2001, Université de Paris, \\ 75015 Paris, France \\ 3 Institut Universitaire de France, CEDEX 05, 75231 Paris, France \\ * Correspondence: olga.soutourina@i2bc.paris-saclay.fr; Tel.: +33-169826206
}

Received: 10 September 2020; Accepted: 13 October 2020; Published: 16 October 2020

\begin{abstract}
The ability of pathogenic bacteria to stably infect the host depends on their capacity to respond and adapt to the host environment and on the efficiency of their defensive mechanisms. Bacterial envelope provides a physical barrier protecting against environmental threats. It also constitutes an important sensory interface where numerous sensing systems are located. Signal transduction systems include Two-Component Systems (TCSs) and alternative sigma factors. These systems are able to sense and respond to the ever-changing environment inside the host, altering the bacterial transcriptome to mitigate the impact of the stress. The regulatory networks associated with signal transduction systems comprise small regulatory RNAs (sRNAs) that can be directly involved in the expression of virulence factors. The aim of this review is to describe the importance of TCS- and alternative sigma factor-associated sRNAs in human pathogens during infection. The currently available genome-wide approaches for studies of TCS-regulated sRNAs will be discussed. The differences in the signal transduction mediated by TCSs between bacteria and higher eukaryotes and the specificity of regulatory RNAs for their targets make them appealing targets for discovery of new strategies to fight against multi-resistant bacteria.
\end{abstract}

Keywords: small regulatory RNAs; TCS-associated RNAs; stress response; two-component systems; alternative sigma factors; genome-wide approaches; mixed regulatory networks; host adaptation; bacterial pathogens; quorum sensing; community behavior

\section{Introduction}

Pathogenic and commensal bacteria that colonize mammalian digestive tract or other host locations are subjected to multiple environment fluctuations. Variations in iron and oxygen concentrations, changes in $\mathrm{pH}$ and temperature, competition with other bacteria for nutrient availability, host defense, and antibiotic stresses are among the parameters that can affect the life cycle of microorganisms [1,2]. Bacteria have developed different strategies to sense and respond to heterogeneous conditions that lead to the adaptation to the new environment and their survival. A well-coordinated gene expression regulation, including the control of virulence factors, underpins this adaptation [3].

Small RNAs (sRNAs) are a class of riboregulators that act generally at post-transcriptional level in all kingdoms of life [4]. Bacterial sRNAs and eukaryotic microRNAs (miRNAs) shared many features for target recognition and modulation of gene expression [5-7]. In this manuscript, we are focusing on bacterial sRNAs and their importance in the adaptation to a changing environment and in virulence control in pathogens. Bacterial sRNAs are small size, usually non-coding and heterogeneous group of molecules that regulate transcription, translation and mRNA stability through diverse mechanisms of 
action. sRNAs can bind proteins or effector molecules for riboswitches, interact with foreign DNA or RNA in the case of clustered regularly interspaced short palindromic repeats (CRISPR) RNA, or form a duplex with mRNA target via base-pairing [4,8]. Base-pairing sRNAs are important post-transcriptional regulators that can either enhance or repress mRNA decay and/or translation by binding in most cases to the $5^{\prime}$ untranslated region (5' UTR) of mRNA. Based on their location with respect to the target, sRNAs are differentiated between cis- and trans-encoded, which could act either in cis or in trans [7,9]. While cis-encoded sRNAs bind the target with perfect complementarity, trans-encoded sRNAs are only partially complementary to their targets and usually require the well-characterized RNA chaperone protein Hfq or ProQ for their action in Gram-negative bacteria [10,11]. The role of Hfq in Gram-positive bacteria is less defined and trans-encoded RNAs may recognize their targets in an Hfq-independent manner [12]. Transcription of most known trans-encoded sRNAs is controlled by transcriptional factors that include Two-Component Systems (TCSs) and alternative sigma factors. TCSs allow adjusting bacterial gene expression in response to environmental cues. Many connections between TCSs and sRNAs have recently been unraveled and it is becoming clear that they form complex regulatory networks in bacteria (Figure 1). Well-documented examples in both Gram-positive and Gram-negative bacteria illustrate this interplay between TCSs and sRNAs. For instance, porin-dependent membrane permeability and quorum-sensing control of pathogenicity involve TCS-regulated sRNAs together with feedback regulatory loops. Several review articles cover various aspects of this large subject [13-16]. In this manuscript, we are reviewing the most recent advances in the characterization of the role of sRNAs related with virulence control in major human pathogens that are connected with TCSs or stress-related sigma factors in complex regulatory circuits. The main approaches for the identification and analysis of these sRNAs will also be discussed as well as perspectives for future applications.

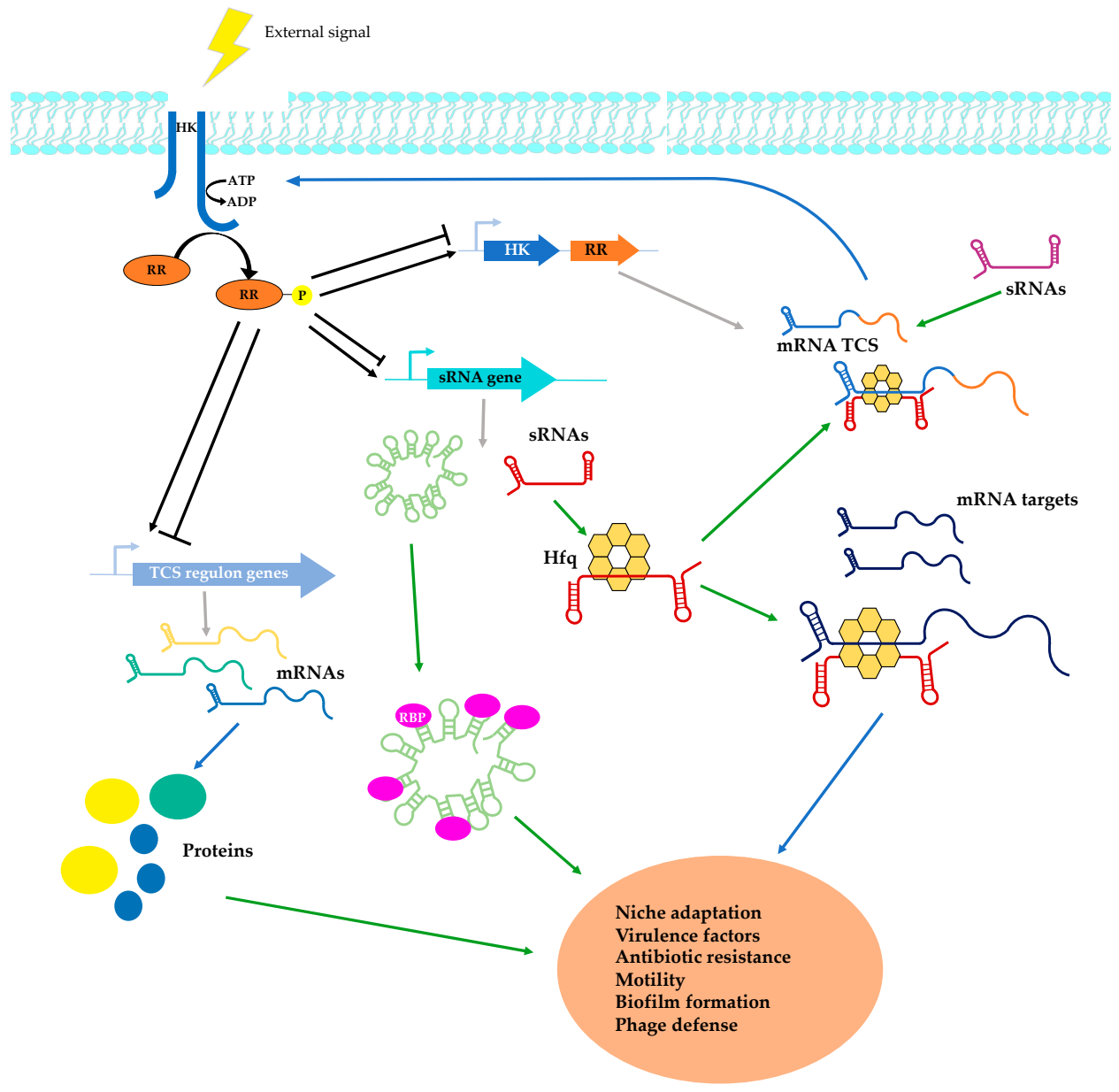

Figure 1. Interplay between regulatory sRNAs and two-component systems during bacterial infection. 
Bacteria sense external signals through TCSs generally composed of the histidine kinase (HK) sensor and the response regulator (RR). Upon stimulation, the HK autophosphorylates on conserved histidine residues, transferring a phosphate group from the adenosine triphosphate (ATP). The phosphoryl group is then transferred to a conserved aspartate in the receiver domain of the RR. This modification activates the RR that will in turn regulate through its DNA-binding domain the expression of specific genes, activating or repressing (black arrows for activation and bar-headed lines for inhibition) their transcription. Genes regulated by phosphorylated RR encode either proteins or regulatory sRNAs. To mediate their regulatory functions, some sRNAs cooperate with chaperone proteins, such as Hfq, and interact with the mRNA target, altering the expression at post-transcriptional level. sRNAs can also sequester RNA binding proteins (RBPs). Upon detection of specific signals, proteins and sRNAs regulated by TCSs contribute to bacterial infection. Finally, TCSs often autoregulate their expression (genes in blue and orange encoding respectively the HK and the RR), altering the level of specific TCSs in the cell. TCS-encoding genes can also be regulated at the post-transcriptional level by sRNAs comprised or not in the regulon of the corresponding TCS. Grey arrows: transcription, blue arrows: translation.

\section{2. sRNAs Regulating Host-Pathogen Interactions}

Crucial steps in the pathogen infection cycle include the capacity to limit and repair damages during host-related stress conditions, to escape the immunity system and to develop antibiotic resistance [17-19]. The regulation of all these steps during host colonization and infection is tightly regulated in pathogens, and sRNAs are important actors in these regulatory processes [16]. Indeed, regulatory events mediated by sRNAs are intimately connected to the transcriptional bacterial network [13]. The expression of many sRNAs is controlled by TCSs (Table 1) and specific stress-responsive alternative sigma factors [13,14,20]. Alternative sigma factors influence the promoter specificity of the core RNA polymerase to direct selective transcription of different gene sets, providing an efficient way for bacteria to rapidly adapt to various environmental changes. The number of sigma factors encoded by different bacterial species varies considerably and generally relates to the diversity of environmental conditions encountered by the organism [21]. Classical TCSs consist of a sensor histidine kinase $(H K)$ and a related response regulator (RR). The sensing of the environmental signal by the HK activates the autokinase domain of the HK, causing the transfer of a phosphoryl group from adenosine triphosphate (ATP) to a conserved histidine residue. The phosphoryl group is then transferred to a conserved aspartate in the receiver domain of the RR. An effector or output domain is present in the RR together with the receiver domain. This domain senses the conformational change induced by the phosphorylation of the aspartate and elicits the specific response [22]. The majority of effector domains have DNA-binding activity and function to activate or repress transcription of specific genes [23]. Most HKs are bifunctional enzymes also displaying phosphatase activity to modulate the phosphorylation level of their cognate RR [23]. Many TCSs contain sRNAs in their regulon, resulting in a fine-tuned gene expression [14]. Similarly to sigma factors, it has been established that the abundance of TCS signaling genes correlates with the lifecycle of bacteria. Specifically, bacteria that colonize multiple habitats usually encode a larger number of these signaling and regulatory proteins, enabling an efficient sensing and response to fluctuations of environment. In contrast, bacteria that primarily live in a uniform habitat encode relatively few TCS signaling genes [24]. 
Table 1. Examples of TCS-associated sRNAs in Gram-negative and Gram-positive bacterial pathogens.

\begin{tabular}{|c|c|c|c|c|c|c|c|}
\hline \multirow{2}{*}{ Pathogen } & \multicolumn{2}{|c|}{ TCS } & \multirow{2}{*}{$\begin{array}{l}\text { sRNA Regulated } \\
\text { by TCS }{ }^{a}\end{array}$} & \multirow{2}{*}{ Targets $\mathbf{b}$} & \multirow{2}{*}{ Roles in Virulence } & \multirow{2}{*}{ Stimuli } & \multirow{2}{*}{ References } \\
\hline & HK & RR & & & & & \\
\hline \multicolumn{8}{|c|}{ Gram-negative bacteria } \\
\hline \multirow{7}{*}{$\begin{array}{l}\text { Escherichia coli, } \\
\text { Salmonella enterica } \\
\text { serovar } \\
\text { Typhimurium }\end{array}$} & CpxA & CpxR & $\begin{array}{l}(+) \text { CpxQ } \\
(-) \text { CyaR } \\
(+) \text { RprA }\end{array}$ & $\begin{array}{l}\text { CpxQ: nhaB (Na-H antiporter), skp (chaperone protein), agp } \\
\text { (periplasmic acid glucose-1-phosphatase), fimA (major } \\
\text { fimbrin subunit of type } 1 \text { pilus) and ydjN (cystine transporter); } \\
\text { CyaR: omp } X \text { (outer membrane protein), luxS (autoinducer-2 } \\
\text { synthase), nadE (essential NAD synthetase) and yqaE } \\
\text { (membrane protein with unknown function), hdeD } \\
\text { (acid-resistance membrane protein); RprA (see below); }\end{array}$ & Envelope-stress response & $\begin{array}{l}\text { High } \mathrm{pH} \text {, osmolality, } \\
\text { alteration in IM lipid } \\
\quad \text { composition }\end{array}$ & {$[25-30]$} \\
\hline & EnvZ & OmpR & $\begin{array}{l}(+) \mathrm{OmrA} \\
(+) \mathrm{OmrB} \\
(+) \mathrm{MicF}\end{array}$ & $\begin{array}{l}\text { OmrA/OmrB: ompT (outer membrane protease), } \operatorname{cir} A, f e c A, \\
f e p A \text {, (receptors for iron-siderophore complexes), } c s g D \text { (TR of } \\
\text { curli genes), flhDC (master regulator of flagellar synthesis) } \\
\text { and ompR-envZ (TCS); } \\
\text { MicF: ompF (outer membrane protein), cpxA-cpxR (TCS), } \\
\operatorname{lrp}(\mathrm{TR}) ;\end{array}$ & Envelope-stress response & Osmolality & {$[31-37]$} \\
\hline & PhoQ & PhoP & $\begin{array}{l}\text { (+) MgrR, } \\
(+) \text { AmgR (in } \\
\text { Salmonella) (+) } \\
\text { PinT (in } \\
\text { Salmonella) }\end{array}$ & $\begin{array}{l}\text { MgrR: eptB (phosphoethanolamine transferase), ygdQ } \\
\text { (hypothetical protein) and soxS (TR involved in oxidative } \\
\text { stress); AmgR: } m g t C \text { (virulence protein); PinT: hilA } \\
\text { (hyperinvasion locus A) and } r t s A \text { (TR) }\end{array}$ & $\begin{array}{c}\text { Resistance to CAMPs, } \\
\text { survival within } \\
\text { macrophages, expression } \\
\text { of type } 3 \text { secretion system } \\
\text { (T3SS) }\end{array}$ & $\begin{array}{l}\text { Low } \mathrm{Mg} 2+/ \mathrm{Ca} 2+ \\
\text { antimicrobial peptides }\end{array}$ & [38-43] \\
\hline & $\begin{array}{c}R \csc C \\
\operatorname{RcsD}^{c}\end{array}$ & $\mathrm{RcsB}$ & (+) RprA & $\begin{array}{c}r p o S \text { (central regulator of the general stress response), } \operatorname{csg} D \\
\text { (TR of curli genes) in } S \text {. Typhimurium, } h d e D \text { (acid-resistance } \\
\text { membrane protein); }\end{array}$ & $\begin{array}{l}\text { Inhibition of biofilm } \\
\text { development and stress } \\
\text { response }\end{array}$ & $\begin{array}{l}\text { Alterations of bacterial } \\
\text { envelope }\end{array}$ & [30,44-46] \\
\hline & $\begin{array}{l}\text { GlrK (QseE } \\
\text { YfhK) }\end{array}$ & $\begin{array}{c}\text { GlrR } \\
\text { (QseF, YfhA) }\end{array}$ & $\begin{array}{l}\text { (+) GlmY and } \\
\text { GlmZ }\end{array}$ & $\begin{array}{l}\text { GlmY: GlmZ; GlmZ: glmS (glucosamine-6-phosphate } \\
\text { synthase), } \\
\text { Locus of Enterocyte Effacement (LEE) } 4 \text { and LEE5 operons, espFu }\end{array}$ & $\begin{array}{l}\text { Antibiotic resistance, } \\
\text { attaching and effacing } \\
\text { (AE) lesion formations }\end{array}$ & $\begin{array}{l}\text { Host hormones such as } \\
\text { epinephrine and } \\
\text { norepinephrine in } \\
\text { Enterohemorrhagic E. coli } \\
\text { (EHEC) }\end{array}$ & [47-50] \\
\hline & QseC & QseB & $(+) G \operatorname{lm} Y$ & & & $\begin{array}{l}\text { Autoinducer } 3(\mathrm{AI}-3) \text { and } \\
\text { the adrenergic hormones }\end{array}$ & [51] \\
\hline & ArcB & ArcA & (-) ArcZ & $\begin{array}{c}r p o S \text { (central regulator of the general stress response), } \\
\text { agrB-agrA } \\
\text { (TCS), flhDC (master regulator of flagellar genes); }\end{array}$ & $\begin{array}{l}\text { Regulation of motility, } \\
\text { host adaptation }\end{array}$ & Aerobic conditions & {$[34,52]$} \\
\hline Helicobacter pylori & ArsS & ArsR & $\begin{array}{l}\text { Cis-antisense } \\
5^{\prime} \text { ureB-sRNA }\end{array}$ & ure $A B$ (urease) & $\begin{array}{c}\text { Colonization of the gastric } \\
\text { mucosa }\end{array}$ & Low $\mathrm{pH}$ & [53] \\
\hline \multirow{3}{*}{ Vibrio cholerae } & LuxPQ $^{d}$ & LuxO & \multirow{2}{*}{ (+) Qrr1-4 } & \multirow{2}{*}{ hapR (master TR), large type 6 secretion system cluster } & \multirow{2}{*}{$\begin{array}{l}\text { Expression of virulence } \\
\text { and biofilm genes }\end{array}$} & \multirow{2}{*}{ Cell density_-AI2 } & \multirow{2}{*}{ [54-57] } \\
\hline & CqsS & LuxO & & & & & \\
\hline & EnvZ & OmpR & (+) CoaR & $\operatorname{tcpI}(\mathrm{TR})$ & $\begin{array}{c}\text { Expression of major pilin } \\
\text { subunit }\end{array}$ & Osmolality & {$[58,59]$} \\
\hline
\end{tabular}


Table 1. Cont.

\begin{tabular}{|c|c|c|c|c|c|c|c|}
\hline \multirow[t]{2}{*}{ Pathogen } & \multicolumn{2}{|c|}{ TCS } & \multirow{2}{*}{$\begin{array}{c}\text { sRNA Regulated } \\
\text { by TCS }^{\text {a }}\end{array}$} & \multirow{2}{*}{ Targets ${ }^{b}$} & \multirow{2}{*}{ Roles in Virulence } & \multirow{2}{*}{ Stimuli } & \multirow{2}{*}{ References } \\
\hline & HK & RR & & & & & \\
\hline \multirow{5}{*}{$\begin{array}{l}\text { Pseudomonas } \\
\text { aeruginosa }\end{array}$} & CbrA & $\mathrm{CbrB}$ & $(+) \mathrm{CrcZ}$ & Sequestration of the RNA-binding protein $\mathrm{Crc}$ & $\begin{array}{c}\text { Metabolism, susceptibility } \\
\text { to antibiotics and } \\
\text { virulence }\end{array}$ & Carbon and nitrogen source & {$[60,61]$} \\
\hline & NtrB & $\mathrm{NtrC}$ & $(+) \mathrm{NrsZ}$ & rhlA (rhamnolipid biosynthesis) & $\begin{array}{l}\text { Increases production of } \\
\text { the virulence factor } \\
\text { rhamnolipid }\end{array}$ & Nitrogen limitation & [62] \\
\hline & NarX & NarL & (+)PaiI & Unknown & Colonization of tumor & Low oxygen and nitrate & [63] \\
\hline & KinB & $\mathrm{AlgB}$ & Type I CRISPR-Cas & & $\begin{array}{l}\text { Immunity to phage } \\
\text { infection }\end{array}$ & Unknown & [64] \\
\hline & PmrA & PmrB & (+) RsmY & Sequestration of the RNA-binding protein RsmA & $\begin{array}{l}\text { Indirect effect on the } \\
\text { expression of } \operatorname{lip} A \text { (lipase) }\end{array}$ & Low $\mathrm{Mg}^{2+}$ & [65] \\
\hline \multicolumn{8}{|c|}{ TCS BarA-SirA and its homologous systems } \\
\hline S. typhimurium & BarA & SirA & (+) CsrB & \multirow{5}{*}{ Sequestration of the RNA-binding protein CsrA/RsmA } & \multirow{5}{*}{$\begin{array}{l}\text { Metabolism, motility, } \\
\text { biofilm formation, stress } \\
\text { resistance, virulence and } \\
\text { quorum sensing }\end{array}$} & \multirow{5}{*}{$\begin{array}{l}\text { BarA senses the presence of } \\
\text { carboxylate compounds. }\end{array}$} & \multirow{5}{*}[54,66-71]{} \\
\hline E. coli & BarA & UvrY & & & & & \\
\hline P. aeruginosa & GacS & GacA & $\begin{array}{l}\text { (+) RsmY } \\
\text { (+) RsmZ }\end{array}$ & & & & \\
\hline $\begin{array}{c}\text { Legionella } \\
\text { pneumophila }\end{array}$ & LetS & LetA & $\begin{array}{l}\text { (+) RsmY } \\
\text { (+) RsmZ }\end{array}$ & & & & \\
\hline V. cholerae & VarS & VarA & $\begin{array}{l}\text { (+) CsrB } \\
(+) \text { CsrC } \\
(+) \text { CsrD }\end{array}$ & & & & \\
\hline \multicolumn{8}{|c|}{ Gram-Positive Bacteria } \\
\hline \multirow[t]{3}{*}{$\begin{array}{l}\text { Listeria } \\
\text { monocytogenes }\end{array}$} & LisK & LisR & (+) LhrC 1-5 & $\begin{array}{l}\text { lapB (virulence adhesin), } \operatorname{tcs} A \text { (T cell-stimulating antigen), } \\
\operatorname{opp} A \text { (oligo-peptide binding protein) }\end{array}$ & $\begin{array}{l}\text { Adhesion and invasion of } \\
\text { non-phagocytic cells, } \\
\text { expression of T } \\
\text { cell-stimulating antigen } \\
\text { TcsA }\end{array}$ & Cell envelope stress & {$[72-76]$} \\
\hline & LisK & LisR & (+) Rli22 & оррА (oligo-peptide binding protein) & $\begin{array}{c}\text { Expression of } \\
\text { virulence-associated } \\
\text { oligo-peptide binding } \\
\text { protein }\end{array}$ & Cell envelope stress & [77] \\
\hline & VirS & VirR & (+) Rli32 & Inducer of IFN- $\beta$ expression; $l h r C$ locus (LhrC1-5) & $\begin{array}{l}\text { Induction of IFN- } \beta \\
\text { expression }\end{array}$ & In vivo infection & {$[78,79]$} \\
\hline
\end{tabular}


Table 1. Cont

\begin{tabular}{|c|c|c|c|c|c|c|c|}
\hline \multirow[t]{2}{*}{ Pathogen } & \multicolumn{2}{|c|}{ TCS } & \multirow{2}{*}{$\begin{array}{l}\text { sRNA Regulated } \\
\text { by TCS }{ }^{a}\end{array}$} & \multirow{2}{*}{ Targets $^{b}$} & \multirow{2}{*}{ Roles in Virulence } & \multirow{2}{*}{ Stimuli } & \multirow{2}{*}{ References } \\
\hline & HK & RR & & & & & \\
\hline $\begin{array}{l}\text { Mycobacterium } \\
\text { tuberculosis }\end{array}$ & PhoR & PhoP & (+) Mcr7 & $\begin{array}{c}\text { tatC (Twin Arginine Translocation (Tat) protein secretion } \\
\text { apparatus) }\end{array}$ & $\begin{array}{c}\text { Secretion of the } \\
\text { immunodominant Ag85 } \\
\text { complex and the } \\
\text { beta-lactamase BlaC }\end{array}$ & Unknown & [80] \\
\hline \multirow{3}{*}{$\begin{array}{l}\text { Staphylococcus } \\
\text { aureus }\end{array}$} & \multirow[t]{2}{*}{ AgrC } & \multirow[t]{2}{*}{ AgrA } & \multirow{2}{*}{$\begin{array}{l}\text { (+) RNAIII } \\
(+) \operatorname{ArtR}\end{array}$} & \multirow{2}{*}{$\begin{array}{l}\text { RNAIII: rot, mgrA (master TRs); spa, coa, sbi, Sa1000, lytM, hla } \\
\text { (virulence factors); ArtR: sarT (TR) }\end{array}$} & $\begin{array}{l}\text { Evasion of host immunity, } \\
\text { toxins expression }\end{array}$ & $\begin{array}{l}\text { Cell density (autoinducers } \\
\text { molecule) }\end{array}$ & {$[81,82]$} \\
\hline & & & & & $\alpha$-toxin expression & Cell density & [83] \\
\hline & SsrB & SsrA & (+) RsaE & $\begin{array}{l}\text { opp3A (ABC transporter component) rocF (arginase involved } \\
\text { in the arginine catabolism). In Staphylococcus epidermidis. } \operatorname{lrg} A \\
\text { (antiholin) icaR (ica } A D B C \text { biofilm operon repressor) and } \\
\text { sucCD (succinyl-CoA synthetase) }\end{array}$ & $\begin{array}{l}\text { Metabolic adaptation, } \\
\text { biofilm formation, eDNA } \\
\text { release. }\end{array}$ & Low $\mathrm{O}_{2}$ and $\mathrm{NO}$ & [84-87] \\
\hline \multirow{3}{*}{$\begin{array}{l}\text { Group A } \\
\text { Streptococcus }\end{array}$} & FasB/FasC & FasA & (+) Fas X & $\begin{array}{l}f a s B C A \text { (TCS), ska (streptokinase), pilus operon, cpa (minor } \\
\text { pilin protein). }\end{array}$ & $\begin{array}{l}\text { Adhesion, motility and } \\
\text { adherence }\end{array}$ & Unknown & [88-90] \\
\hline & $\mathrm{CiaH}$ & CiaR & (+) 5 csRNAs & com C (precursor of the competence stimulating peptide) & $\begin{array}{l}\text { Competence, genomic } \\
\text { plasticity }\end{array}$ & Unknown & [91] \\
\hline & CovS & CovR & (+) RivX & possibly mga (master TR) & $\begin{array}{l}\text { Mga regulates genes } \\
\text { important for virulence in } \\
\text { the host }\end{array}$ & Unknown & [92] \\
\hline $\begin{array}{l}\text { Clostridium } \\
\text { perfringens }\end{array}$ & VirS & VirR & $\begin{array}{l}\text { (+) VR-RNA } \\
\text { VirT, VirU }\end{array}$ & VR-RNA: plc (Phospholipase C), colA (k-toxin) & Expression of toxins & & [93-97] \\
\hline
\end{tabular}

${ }^{a}$ TCSs may control the expression of the sRNA in a positive (+) or negative (-) way. ${ }^{b}$ The sRNA name is specified when multiple sRNAs are regulated by the TCS. TCSs as sRNA targets are in bold. TR: Transcriptional Regulator. ${ }^{c}$ The Rcs system is a non-ortholog TCS composed of the transmembrane sensor kinase RcsC, the transmembrane protein RcsD, and the response regulator RcsB. ${ }^{\mathrm{d}} \mathrm{AI}-2$ is detected by the periplasmic protein LuxP in complex with the LuxQ histidine kinase. Phosphate is then transduced to a single phosphotransfer protein, LuxU, which in turn transfers the phosphate to a response regulator called LuxO. 


\section{1. sRNAs Involved in Stress Response}

Bacteria encounter numerous stresses when they enter in contact with the host [98]. The envelope is a physical barrier that protects against environmental stresses and constitutes a crucial interface for host-pathogen interactions. To adapt to the host environment, bacteria have developed general stress responses and Envelope Stress Responses (ESR) [17,99]. The alternative sigma factors $\sigma^{\mathrm{S}}$ or $\sigma^{\mathrm{B}}$ orchestrate the general stress reponse in Gram-negative bacteria and Gram-positive bacteria respectively [99], while ERSs are mediated by the alternative sigma factor $\sigma^{\mathrm{E}}$ and several TCSs including PhoPQ and EnvZ/OmpR. In this section, we will present new sRNAs present in stress-associated regulatory networks and we will discuss such regulations for major human pathogens.

\subsection{1. sRNAs Regulated by Alternative $\sigma$-Factors}

The alternative sigma factor $\sigma^{B}$ modulates the general stress response of several Gram-positive bacteria. This sigma factor is responsible for the transcription of genes that confer stress resistance to the vegetative cell and is important for virulence [100]. In Staphylococcus aureus, the transcription of the sRNA RsaA is $\sigma^{\mathrm{B}}$-dependent [101]. RsaA activates the production of biofilm and inhibits the capsule synthesis through the repression of the master regulator MgrA translation. RsaA base-pairs with mgrA mRNA in two different regions: one next to the ribosome-binding site (RBS) and the other in the coding sequence [102]. The duplex formation leads to the sequestration of the RBS and to the recruitment of RNase III to degrade the duplex. Although MgrA is the main target of RsaA, other targets, such as mRNAs for cell wall hydrolases and FLIPr, a secreted immunomodulatory molecule, have been identified [103]. Using mouse infection models, RsaA was shown to diminish invasiveness but enhance local colonization, favoring chronic infection [102].

In Listeria monocytogenes, expression of at least two sRNAs, SbrA and Rli33-1, is directly controlled by $\sigma^{\mathrm{B}}[104,105]$. While the function of SbrA remains to be investigated, Rli33-1 plays a role during infection [106]. Rli33-1 sRNA belongs to the multicopy family LhrC, encompassing 7 members [77]. Besides Rli33-1, LhrC sRNAs, comprising LhrC1-5 and Rli22, are positively regulated by the TCS LisRK that responds to cell envelope stress [71,72,76,77]. Transcription of all LhrC sRNAs except Rli22 is strongly induced during intracellular bacterial growth in murine macrophages. In addition, a deletion mutant of Rli33-1 is affected in its survival in murine macrophages and is less virulent in Galleria mellonella and murine infection models [106]. All LhrC sRNAs are also highly induced when L. monocytogenes is exposed to human blood, and the expression of members LhrC1-5 is increased in the presence of excess heme, the core component of hemoglobin $[76,107]$. The LhrC family of sRNAs negatively regulates the same mRNA targets through base-pairing to the RBS region, resulting in inhibition of translation or a decrease of mRNA stability $[72,74,75,77]$. LhrC targets include three surface-exposed proteins involved in virulence, the adhesin LapB, the oligopeptide-binding protein OppA and the CD4 ${ }^{+} \mathrm{T}$ cell-stimulating antigen TcsA. In addition, strong evidence suggests that the heme-binding proteins $\mathrm{Hbp} 1$ and $\mathrm{Hbp} 2$, and the heme oxygenase-like protein Lmo0484 involved in heme uptake and utilization are other members of the LhrC regulon, further reinforcing a link between the response to heme toxicity and cell envelope stress in L. monocytogenes [76].

In Escherichia coli, several sRNAs are involved in the regulatory network of the general stress response sigma factor $\sigma^{S}$ (for a detailed review on the general stress response mediated by $\sigma^{S}$ in bacteria see [108]).

Unassembled outer membrane proteins (OMPs) and lipopolysaccharides (LPS) damages caused by physical and chemical stresses generally trigger the ESR $\sigma^{\mathrm{E}}$-dependent response in Gram-negative bacteria [109]. Upon stimulation, the activation of $\sigma^{\mathrm{E}}$ is mediated by a regulated inter-membrane proteolysis (RIP) [110] that results in the cleavage of the inhibitor anti- $\sigma$ factor RseA and the release of $\sigma^{\mathrm{E}}$ in the cytoplasm. $\sigma^{\mathrm{E}}$, as a cofactor of RNA polymerase, recognizes specific promoters and initiates the transcription of around 100 genes implicated in outer membrane (OM) modifications and repair [100].

In Salmonella and E. coli, $\sigma^{\mathrm{E}}$-regulated sRNAs repress protein synthesis of all of the most abundant OMPs. The strongest promoters recognized by $\sigma^{\mathrm{E}}$ drive the transcription of two sRNAs: MicA and RybB [111]. These two Hfq-dependent sRNAs act as posttranscriptional repressors and bind with a limited base-pairing the 5' UTR of target mRNAs, altering their translation and stability [112]. MicA and RybB both repress the synthesis of several major OMPs to limit the production of these components when the OM is damaged [112,113]. In E. coli, deletion of $r p o E$, the gene encoding $\sigma^{\mathrm{E}}$, is lethal [114], but it has been shown that MicA and RybB can rescue the cells from lethality associated with loss of $\sigma^{\mathrm{E}}$ activity [112]. Thus, an adequate activation of these two sRNAs is 
essential and the promoter strength of mic $A$ and $r y b B$ underlies their physiological importance in balancing the OM during stress conditions. Interestingly, these two sRNAs share the regulation of some targets, such as omp $A$, in non-overlapping regions, suggesting that they might need to cooperate to achieve optimal repression [112].

Besides MicA and RybB, $\sigma^{\mathrm{E}}$ regulates an additional Hfq-dependent sRNA, MicL in E. coli and Salmonella. This sRNA inhibits the expression of the most abundant OM lipoprotein Lpp by specifically targeting the corresponding mRNA, which tethers the OM to the peptidoglycan layer [115].

In Vibrio cholerae, $\sigma^{\mathrm{E}}$ activates the expression of two other Hfq-dependent sRNAs, VrrA and MicV. VrrA recognizes the $5^{\prime}$ region of the ompA mRNA, repressing its translation and causing increased release of OM vesicles (OMVs). OMVs are important for niche colonization, transport of virulence factors into host cells, modulation of host defense, and response and communication with the surrounding environment. Accordingly, a vrr $A$ mutant showed increased ability to colonize the small intestine of mice as compared with the wild type [116,117]. VrrA also represses the major OMP OmpT, the biofilm matrix protein RbmC and the ribosome-binding protein Vrp, involved in starvation survival [118-120]. The second sRNA, MicV, shares the same seed-pairing domain as VrrA and more than 23 genes are targeted by both sRNAs including the genes encoding OMP OmpA and OmpT, suggesting a redundant function of VrrA and MicV [121].

\subsubsection{Other ESR-Regulated sRNAs}

The PhoPQ TCS is another transduction system that responds to cell envelope damage and significantly remodels the envelope. In Salmonella enterica serovar Typhimurium, PhoPQ is a major regulator of virulence and is activated by exposure to low $\mathrm{pH}$, divalent cations such as $\mathrm{Mg}^{2+}$ and $\mathrm{Ca}^{2+}$, and cationic antimicrobial peptides (CAMPs) [122]. Genes encoding OMPs, IM transporters that buffer the cytosolic $\mathrm{pH}$ and enzymes for the modification of the LPS are among those positively regulated by the activated PhoP (see review [122] for further details). The remodeling of LPS alters the interaction with CAMPs, providing resistance against these molecules [123-125]. In the regulatory control of the LPS, the PhoPQ TCS activates the expression of the MgrR sRNA. Specifically, this Hfq-dependent sRNA inhibits the synthesis of the LPS phosphoethanolamine transferase EptB by binding the 5' UTR of the corresponding mRNA. Deletion of the MgrR sRNA results in expression of eptB and is associated with a higher resistance to the CAMP Polimixin B [38].

PhoPQ also induces the transcription of the Hfq-binding sRNA PinT, which is involved in the regulation of the expression of genes located in the pathogenicity island 1 (SPI-1) of Salmonella [41-43]. Type III secretion system (T3SS) encoded by SPI-1 is important for the invasion of macrophages and intestinal epithelial cells. Three regulatory proteins, HilD, HilC, and RtsA activate the transcription of the hilA gene, encoding the transcriptional activator of the structural and primary effector genes of the SPI-1 T3SS apparatus. Once inside the phagosome of the eukaryotic cells and during systemic infection, genes required for intracellular survival are expressed while the SPI-1 gene expression is shut off. The PhoPQ TCS inhibits SPI-1 gene expression by directly repressing hilA transcription. In addition, the sRNA PinT inhibits hilA and $r$ ts $A$ translation. PinT base-pairs with a region close to the AUG translation initiation codon of hilA and rst $A$ mRNAs. This interaction blocks translation of hilA and $r s t A$ mRNA by inhibiting the ribosome binding and triggers the degradation of the $r t s A B C D$ polycistronic mRNA by the RNA degradosome [42]. Besides its regulatory role on SPI-1 gene expression, PinT directly represses the translation of $s s r B$, encoding the primary regulator of the pathogenicity islands 2 (SPI-2) T3SS and inhibits motility by repressing crp, a cAMP receptor protein-encoding gene involved in the activation of the flagellar master regulatory genes flhDC [42]. Importantly, a pinT mutant outcompetes the wild-type strain during systemic stages of infection in competition assays [42].

In addition to MgrR and PinT, PhoPQ also regulates the expression of a cis-encoded long antisense RNA named AmgR that is transcribed from an intergenic region located between the $m g t C-m g t B$ genes within the $m g t C B R$ polycistronic messenger. $\mathrm{MgtC}$ is an inner membrane protein critical for intramacrophage survival and mouse virulence and involved in growth in low $\mathrm{Mg}^{2+}$ conditions; $\mathrm{MgtB}$ is a $\mathrm{Mg}^{2+}$ transporter; and $\mathrm{MgtR}$ is a short peptide regulator that binds MgtC, promoting MgtC degradation by the protease FtsH [126]. The AmgR transcription reduces the $\mathrm{MgtC}$ and $\mathrm{MgtB}$ protein levels in an $\mathrm{Hfq}$-independent manner requiring the RNAse E. Conversely, $a m g R$ deletion increases the level of the same proteins, enhancing bacterial virulence [40]. AmgR is also required for replication in a low $\mathrm{Mg}^{2+}$ environment [40]. Interestingly, expression of AmgR and its target 
mRNA is controlled by the same regulator since PhoP-P also recognizes and activates the transcription from $m g t C B R$ promoter. Thus, two negative regulators of $\mathrm{MgtC}, \mathrm{AmgR}$ and $\mathrm{MgtR}$, are expressed under the same conditions. Nevertheless, they make different contributions to Salmonella virulence as an amgR promoter mutant is hypervirulent in mice, unlike a $m g t R$ deletion mutant $[40,126]$. Thus, AmgR plays an important role in the survival of Salmonella within macrophages and in its virulence in mice $[40,127]$.

High osmolarity in the intestinal lumen of the host is an important stress faced by gut pathogens. In E. coli, the EnvZ/OmpR TCS senses osmotic stresses and differently regulates the synthesis of OmpF and OmpC, the two major porins that facilitate the diffusion of small hydrophilic solutes across the OM [128]. When osmolarity increases, OmpR activates the expression of the sRNA MicF. MicF prevents the translation initiation of ompF by direct base-pairing to a region of the ompF mRNA encompassing both the RBS and the start codon [36]. The repression of $\mathrm{OmpF}$ contributes to the protection of the cell during high osmolarity conditions. Indeed, the pore diameter of $\mathrm{OmpF}$ is larger than that of $\mathrm{OmpC}$ and when expressed is responsible for a faster diffusion rate of osmolytes [129]. Porins mediate the passive diffusion of antibiotics across the OM and are associated with antibiotic resistance in the Gram-negative bacteria. In line with this notion, overexpression of MicF increases $E$ coli resistance to different antibiotics, including cephalosporins, while MicF depletion has an opposite effect [130,131].

The EnvZ/OmpR regulon includes two other Hfq-dependent sRNAs, OmrA and OmrB, involved in the regulation of the OM composition. These two sRNAs are positively regulated by OmpR and are redundant on most targets, using their almost identical $5^{\prime}$ tails for base-pairing [32]. Proteins repressed by OmrA and OmrB include many OMPs such as the protease OmpT and the iron transporters CirA, FecA, and FepA. To date, the functional link between the iron transport inhibition and the EnvZ/OmpR activation remains unclear [31].

The sRNAs OmrA/B also play important roles in the regulation of the flagellar synthesis and biofilm formation by targeting master regulatory genes. Bacterial flagellum synthesis genes form an ordered cascade in which the expression of one gene at a given level requires the transcription of another gene at a higher level. The flagellar synthesis master regulator FlhDC is encoded in the class I operon and activates the transcription of the class II sigma factor fliA $\left(\sigma^{28}\right)$ and anti-sigma factor flgM. FliA is held inactive through direct protein interaction with FlgM and directs expression of the class III genes upon secretion of FlgM [132]. OmrA and OmrB base-pair with the $5^{\prime}$ UTR of flhDC and the early coding region of flgM, inhibiting translation in both cases [33,34]. Thus, OmrA/B repress the initial step of the flagellar pathway via FlhDC, but also activate FliA and the subsequent class III gene expression via FlgM repression. OmrA/B also target the transcript of the master regulator of biofilm formation CsgD [33], inhibiting $\operatorname{csg} D$ gene expression [133,134]. Interestingly, OmrA/B post-transcriptionally regulate the expression of $\operatorname{ompR}$ by base-pairing with its 5' UTR, forming a negative feedback regulatory loop [31,32].

In $V$. cholerae, high osmolarity and acid stress induce the expression of the CoaR sRNA via the EnvZ/OmpR TCS. CoaR targets the tcpI gene encoding the negative regulator of the major pilin subunit TcpA, which is important for host colonization. Accordingly, the deletion of this sRNA negatively impacts the colonization of the small intestine of mice [58,59].

\subsection{TCS-Associated sRNAs Involved in Quorum-Sensing Signaling}

Quorum sensing is a signaling process that allows community-wide coordination and collective behaviors in bacteria. The signaling molecules activating the quorum sensing are the extracellular autoinducers (AIs). The concentration of AIs is proportional to the bacterial cell density. Once activated, quorum sensing signaling modulates gene expression [135]. Important virulence-associated sRNAs participate in this regulatory network [135]. The switching to the community behavior, in some pathogens, includes the induction of virulence phenotype [136].

In S. aureus, the quorum sensing signaling is regulated by the agr locus, which includes the well characterized sRNA RNAIII. This locus comprises two open reading frames (ORFs) whose transcription is initiated from two promoters named P2 and P3 that are located in divergent orientations in the chromosome [82]. The P2 promoter regulates the transcription of the polycistronic RNA, RNAII, encoding the AgrBDCA proteins. AgrB and AgrD are responsible for the synthesis, maturation and secretion of the AI peptide (AIP) while AgrC and AgrA form a TCS [82]. AIP, which serves as an indicator of the local population density, binds to the sensor kinase AgrC that 
in turn activates AgrA by phosphorylation. AgrA-P recognizes sites in the P2 and P3 promoters, activating the transcription of RNAII and RNAIII, respectively [82].

The $514 \mathrm{nt}$ sRNA RNAIII is one of the main intracellular effectors of the agr system and plays a key role in the virulence of $S$. aureus by controlling the switch between early expression of surface proteins and late expression of several exotoxins [81]. Interestingly, RNAIII acts as a dual function RNA since it also encodes in its 5' end a small toxin, the phenol-soluble modulin (PSM) $\delta$-hemolysin, that confers hemolytic activity to the bacterium [82]. RNAIII is a very structured sRNA with 14 stem loops involved in base pairing-dependent regulation of mRNA targets [137]. To date, many direct RNAIII targets have been identified, including two transcriptional regulators by means of which RNAIII indirectly modulates the transcription of many secondary targets [82]. It should be noted that the interaction between RNAIII and its direct mRNA targets does not require the RNA chaperone protein Hfq [138]. RNAIII acts both as a repressor and an activator of translation. Target repression is achieved through inhibition of ribosome binding, thus preventing translation initiation and frequently stimulating the specific recognition and degradation by RNase III [139]. RNAIII also stimulates translation of three mRNA targets for the global regulatory protein MgrA, the $\alpha$-hemolysin Hla and the extracellular adherence protein Map. Binding of both the 5' and the 3' end of RNAIII to the 5' UTR of MgrA mRNA leads to the stabilization of the MgrA transcript and enhances MgrA production. This regulator acts as a repressor of biofilm formation and cell autolysis and as an activator of the agr locus and capsule gene expression [82,140]. The mechanism for Hla activation is more original with the binding of RNAIII to the 5' UTR of hla, releasing the RBS, which is otherwise sequestered by intramolecular base-pairing [141]. Activation of Map by RNAIII might be mediated by a similar mechanism but has not been studied in detail [142].

RNAIII is a posttranscriptional regulator of multiple virulence genes that plays a key role in the late stages of infection by mediating the switch between adhesion and invasion [143]. In line with this statement, many clinical isolates from acute infection express RNAIII [144]. Targets whose translation is repressed by RNAIII are implicated in the early stages of infection and include surface proteins important for the adhesion and immune evasion (protein A encoded by spa [145], coagulase encoded by coa, immunoglobin-binding protein encoded by $s b i$ [146], and fibrinogen-binding protein SA1000 [143]). Conversely, RNAIII activates synthesis of exotoxins both directly (induction of $\delta$-hemolysin and $\alpha$-hemolysin synthesis) and indirectly via the negative regulation of Rot, a transcriptional factor repressing the expression of several toxins [143].

Interestingly, agr defective strains have been isolated from patients colonized by S. aureus [147,148]. These isolates have lost the ability to disseminate in the host but are associated with persistent bacteremia and are thought to be positively selected during chronic infection and dormant states, a situation associated with biofilm formation [16,82].

In S. aureus, AgrA also activates the transcription of psm-mec, a dual function RNA that encodes the 22 amino-acid PSM-mec cytolysin [149] and directly interacts with agrA mRNA, inhibiting agrA translation. AgrA repression leads to a decrease of toxin production and the attenuation of virulence in mice [150]. Interestingly, psm-mec, which is transcribed from the SCCmec mobile genetic element, is present in the hospital associated-methicillin resistant $S$. aureus but absent in the more virulent community-acquired methicillin-resistant S. aureus, suggesting a correlation between high virulence and absence of psm-mec [150].

Finally, the AgrAC TCS of S. aureus represses the expression of an sRNA designated ArtR [83]. ArtR directly binds, in an Hfq-independent manner, to the 5' UTR of sarT mRNA, thus promoting the duplex degradation by RNase III. SarT is a repressor of the $\alpha$-hemolysin virulence factor Hla and, therefore, ArtR indirectly activates the expression of hla.

The agr locus is also present in the genome of other Gram-positive bacteria such as Enterococcus faecalis, L. monocytogenes, Clostridium botulinum, and Clostridioides difficile [151-154]. An agr deletion in these bacteria is associated with a decrease of the virulence, but no sRNAs have been found yet in their regulon [151-154]. In Clostridium perfringens, the agr-like operon does not contain a TCS but it has been suggested that VirS/VirR could serve this function instead [155]. Interestingly, the VirS/VirR regulon comprises an important sRNA, VR-RNA [93]. This $386 \mathrm{nt}$ sRNA is involved in the regulation of 147 genes including the $\alpha$-toxin (or phospholipase C) encoded by plc and the k-toxin (or collagenase) encoded by colA [94,95]. The mechanism of activation of colA translation by 
VR-RNA has been investigated [96]. VR-RNA base-pairs with the 5' UTR of colA mRNA, leading to the cleavage of this extremity and to the subsequent stabilization of colA mRNA.

\subsection{TCS-Associated sRNAs Involved in CRISPR-Cas Immunity and Competence Control}

During infection, pathogens need to cope with the presence of genetic invaders like bacteriophages and other sources of foreign nucleic acids. The bacterial life-style within high cell density communities favors viral predation and genetic exchanges through horizontal gene transfer (HGT) [156]. Depending on the nature of the new genetic information, the outcome of its uptake can be either deleterious or beneficial for bacterial survival in host environments. For this reason, the efficiency of protective mechanisms and the acquisition of new genetic elements need to be tightly balanced. Bacteria have developed sophisticated mechanisms for these two antagonistic functions of defense against genetic invaders and HGT. Thus, the regulation of defense systems including CRISPR-Cas on the one hand and new DNA acquisition mechanisms including natural competence systems on the other hand is extremely important for bacterial adaptation to changing environments with fitness cost considerations. Recent studies provided new examples of such regulatory mechanisms involving sRNAs under the control of TCS in major pathogens [64,157-161].

Together with many community-level behaviors, quorum sensing has been recently shown to control CRISPR-Cas-mediated immunity in bacteria, including pathogens [157-159]. The regulatory components of the LuxIR-like TCS quorum sensing system in Gram-negative bacteria, named SmaIR in Serratia and LasIR/RhlIR in Pseudomonas aeruginosa, induce the expression of cas operons and CRISPR arrays of multiple CRISPR-Cas systems of type I-E, I-F and III-A, thus affecting both interference and immunity acquisition functions of CRISPR-Cas $[157,158]$. The link between quorum sensing and CRISPR-Cas regulation was recently further confirmed by studies in P. aeruginosa clinical strains, demonstrating the potential of a quorum quenching enzyme degrading quorum-sensing signaling molecules to modulate CRISPR-Cas expression [159]. Quorum sensing was shown to act synergistically with another cue, low environmental temperature associated with slow growth, to control CRISPR-Cas function in this pathogen [162].

In addition to adaptive immunity, noncanonical functions have been suggested for the components of CRISPR-Cas systems (Cas proteins, crRNAs and other CRISPR-associated RNAs) that are implicated in the control of bacterial pathogenesis and physiology [163-167]. The molecular mechanisms of CRISPR-Cas-mediated control of gene expression remain in many cases to be explored, but important links of these regulatory processes with virulence, biofilm formation and envelope stress response could be emphasized in several pathogens, i.e., Francisella novicida, Neisseria meningitidis, Campylobacter jejuni, Legionella pneumophila, L. monocytogenes, and P. aeruginosa $[164,166,168]$. Interestingly, a recent work suggests targeting of quorum-sensing systems by CRISPR-Cas in Salmonella to mediate virulence and biofilm formation regulation [168].

Besides quorum-sensing, recent studies revealed the role of other TCS in the regulation of CRISPR-Cas systems [64,160]. In P. aeruginosa, KinB-AlgB TCS, involved in extracellular polysaccharide alginate biosynthesis, has been identified as a regulator of expression and activity of type I-F CRISPR-Cas [64]. This work provides an example of how a CRISPR-Cas system is controlled during lifestyle transitions in this opportunistic pathogen. In the cariogenic bacterium Streptococcus mutans, VicR/K, a TCS important for biofilm formation, competence, stress tolerance and bacteriocin production, is implicated in the control of type I-C and type II-A CRISPR-Cas to modulate stress response, DNA repair and natural transformation [160].

Despite the crucial importance of defense against mobile genetic elements, HTG provides a powerful mechanism to acquire new traits contributing to bacterial adaptation and survival. An important human pathogen, Streptococcus pneumoniae, is able to uptake new DNA through natural competence induction. Several sRNAs are implicated in the competence control of this bacterium [161,169-171]. This includes the sRNA, srn206, which is essential for competence initiation and targets the comD gene, encoding the histidine kinase of the ComDE TCS [170]. Five sRNAs of 87-151 nt in length named csRNA1-5 (for cia-dependent small RNAs), sharing high sequence similarity, have been identified as members of CiaRH TCS regulon [161,171]. This TCS, highly conserved among streptococci, affects $\beta$-lactam resistance, autolysis, virulence, and competence development. The competence control is mediated by five csRNAs whose expression is driven by the five strongest promoters within the CiaRH regulon. Target predictions and translational-fusion analysis identified the com C gene, encoding 
the precursor of competence-stimulating peptide, as a target of csRNAs [171]. By inhibiting comC translation, csRNA could block the competence initiation process linking CiaRH to competence control.

\subsection{Signal Transduction Systems-Associated Riboswitches}

Riboswitches are highly structured cis-acting elements located at the 5' UTR of mRNAs that are involved in the regulation of gene expression upon binding of specific molecules (reviewed in [172]). Currently, almost 40 distinct classes of riboswitches binding diverse ligands such as metabolites or ions have been identified [173]. While several riboswitches have been shown to contribute to bacterial pathogenicity (reviewed in [174]), only a few are associated with TCS or specific sigma factors. Examples are developed below.

Cyclic diguanylate monophosphate (c-di-GMP) is a second messenger in bacterial systems and a key feature in the control of critical lifestyle choices, such as the transition between planktonic and biofilm growth [175]. Elevated levels of c-di-GMP typically promote sessile lifestyles such as biofilm formation; in contrast, low levels of c-di-GMP are associated with motility [175]. C. difficile 630 encodes 18 predicted diguanylate cyclases and 19 predicted phosphodiesterases, many of which have confirmed enzymatic activity [176]. In addition, C. difficile 630 encodes 16 class I and class II c-di-GMP sensing riboswitches [177], underlining the importance of c-di-GMP signaling in this human pathogen. The $f l g B$ operon, encoding flagellar genes and the flagellar sigma factor $\sigma^{\mathrm{D}}$, is preceded by the Cdi1_3 c-di-GMP-responsive riboswitch in C. difficile [177-179]. C-di-GMP binding to Cdi1_3 in the $5^{\prime}$ UTR of the $f l g B$ operon mRNA causes premature termination of transcription and consequently leads to a decrease in the transcription of the flgB operon [177-179]. Interestingly, $\sigma^{\mathrm{D}}$ positively controls TcdR, an alternative sigma factor that directs transcription of the toxin-encoding genes $t c d A$ and $t c d B$ for the main virulence factors of $C$. difficile [180]. Thus, by repressing $\sigma^{\mathrm{D}}$ transcription in the presence of high c-di-GMP levels, the Cdi1_3 riboswitch indirectly represses the synthesis of TcdA and TcdB.

Another c-di-GMP-responsive riboswitch, Cdi2_2, precedes the genes encoding the signal transduction system CmrRST in C. difficile, where CmrS is a putative histidine kinase, and CmrR and CmrT are two predicted response regulators [181]. Binding of c-di-GMP to Cdi2_2 positively affects cmrRST expression [182], most likely through anti-termination of transcription. Interestingly, cmrRST is also regulated by phase variation with an invertible DNA sequence, the cmr switch, located upstream of the corresponding genes [182]. CmrRST modulates colony morphology (rough or smooth) with the activation of cmrRST expression by c-di-GMP binding to Cdi2_2, promoting the development of rough colonies. CmrRST also inversely regulates motility and surface migration and promotes bacterial chaining. Importantly, a cmrR deletion mutant is unable to colonize the intestinal tract and has a strong virulence defect in the hamster model of infection [182].

In Enterococcus faecalis and L. monocytogenes, a riboswitch responding to vitamin $\mathrm{B}_{12}$ controls the transcription of trans-acting sRNAs EutX and Rli55, respectively, which both sequester the EutV response regulator of the EutVW TCS $[183,184]$. In these two pathogens, ethanolamine is sensed by the sensor kinase EutW, which results in the activation of EutV. EutV is a member of the ANTAR (AmiR and NasR transcriptional antiterminator regulators) family of response regulators that binds RNA rather than DNA and controls gene expression through transcription antitermination [185]. Specifically, EutV binds ANTAR elements in the 5' UTR of eut mRNAs, whose products enable ethanolamine utilization, preventing the formation of a transcription terminator to activate eut expression. However, an ANTAR binding site is also present within sRNAs EutX and Rli55. Thus, when vitamin $\mathrm{B}_{12}$, a cofactor required for ethanolamine catabolism, is absent, EutX and Rli55 are synthesized and sequester the activated EutV to inhibit the expression of the eut genes. In contrast, when present, vitamin $\mathrm{B}_{12}$ binds to the riboswitch, which leads to premature termination of transcription and prevents the synthesis of the sRNAs. Consequently, EutV is not sequestered and eut expression is activated. Importantly, constitutive expression of EutV sRNA in a riboswitch deletion mutant significantly attenuates L. monocytogenes virulence in a mouse intravenous infection model [184].

\subsection{Other TCS-Associated sRNAs Involved in Virulence}

From numerous examples covered in this review, it is evident that TCSs in concert with sRNAs play a crucial role in virulence control in major pathogens. Recent studies described in this part illustrate the TCS-dependent control of virulence factor gene expression that is mediated by sRNAs in Streptococcus. 
In the group A Streptococcus (GAS), fas X encodes an sRNA regulated by the FasBCA system, which comprises two sensor histidine kinases (FasBC) and one response regulator (FasA) [89,186]. The $205 \mathrm{nt}$ fasX is the fourth gene of the $f a s B C A X$ locus and the transcription of this sRNA is growth phase-dependent with the higher expression levels occurring during the transition between the exponential and stationary phases of growth [89,187]. However, the specific signals leading to the activation of FasBCA remain to be defined. FasX has both positive and negative regulatory targets and was proposed to function as a master regulator governing the transition between colonization and dissemination [186]. On the one hand, FasX inhibits the translation of pili mRNAs and of prtF1 and prtF2 encoding fibronectin-binding proteins by base-pairing to sites overlapping the respective RBS [88,186,188]. Interestingly, FasX-mediated regulation of pilus genes occurs in a serotype-specific manner with FasX interacting with different mRNA sequences or different mRNA pilus biosynthesis genes in each serotype [188]. On the other hand, FasX positively affects the production of the thrombolytic agent streptokinase by base-pairing to the 5' UTR of ska mRNA and forming a secondary structure, which enhances the stability of the mRNA $[88,89,188]$. FasX was shown to reduce GAS adherence and promote virulence in a bacteremia model using human plasminogen-expressing mice [88,188].

The TCS CovRS, a major global regulator of GAS virulence, directly or indirectly represses transcription of approximately $15 \%$ of the GAS genes [189]. Direct targets of CovR include the riv operon genes rivR and rivX, encoding respectively a transcriptional regulator and an sRNA [92,190]. The function of RivR and RivX remains controversial. RivR and RivX were first shown to positively regulate in an independent manner the expression of regulon members of the virulence gene regulator Mga [92]. However, these data were not corroborated in a more recent report and no regulatory functions could be attributed to RivX [191]. In addition, the virulence of a rivRX deletion mutant is attenuated [92,191], but the specific contribution of RivX to this phenotype is unclear.

\section{Participation of sRNAs in Regulatory Networks}

As illustrated in this review, TCSs in concert with sRNAs allow pathogenic bacteria to quickly sense and respond to different stimuli during host colonization. TCSs and stress-related sigma factors, regulatory RNAs and their protein partners constitute the major components of mixed regulatory networks to tightly control gene expression (Figure 1). It is important to emphasize that in many cases the expression of sRNA genes is controlled by TCSs (Table 1) and alternative sigma factors establishing a link between environmental conditions and downstream sRNA-mediated regulations. sRNAs in turn are involved in the control of gene expression for other regulatory components including sometimes their own transcriptional regulator or a different system. Such examples of feedback regulatory loops on sRNAs controlling TCSs are highlighted in Table 1. We have selected recent studies notably on sRNAs in Gram-negative and Gram-positive bacteria. The most extensively studied case of interconnection between TCS and sRNAs is OmrA and OmrB sRNAs regulated by OmpR-EnvZ TCS, which is in turn controlled by the same sRNAs [32]. Remarkably, the regulons of different TCSs usually contain several regulatory RNAs, leading to complex overlapping circuits allowing better integration of external signals. Intriguingly, in many cases, several homologous sRNAs are implicated in TCS signaling pathways with additive (e.g., V. harveyi Qrr1-5) or redundant (e.g., E. coli CsrB-C, V. cholerae Qrr1-4) action [14]. TCSs have been identified as targets for a number of sRNAs for which TCS-dependent regulation has not been uncovered. This connection allows to expand the regulatory potential of sRNA including associated TCS regulon. Specific examples of sRNAs targeting TCS genes are presented in Table 2. Such regulatory connections have recently been described in both Gram-negative and Gram-positive pathogens and are associated with stress response, colony morphology, motility, competence control, and other virulence-related processes [13,192]. 
Table 2. Examples of sRNAs regulating TCSs.

\begin{tabular}{cccc}
\hline Pathogen & $\begin{array}{c}\text { sRNA Regulating } \\
\text { TCS }\end{array}$ & Regulated TCS & References \\
\hline & Gram-negative Bacteria & & \\
\hline Escherichia coli & RybC & DpiA-DpiB & {$[193]$} \\
E. coli & SdsN & NarQ-NarP & {$[194]$} \\
E. coli, Salmonella & GcvB, MicA & PhoP-PhoQ & {$[195,196]$} \\
\hline Staphylococcus aureus & Gram-positive Bacteria & & {$[150]$} \\
Clostridioides difficile & psm-mec & AgrA-AgrC & {$[182]$} \\
Streptococcus pneumoniae & Cd2-2 & CmrR-CmrS-CmrT & {$[170]$} \\
Enterococcus faecalis, Listeria monocytogenes & srn206 & ComD-ComE & {$[183,184]$} \\
\hline
\end{tabular}

The advantages of combining sRNA-mediated regulation with protein-mediated control are multiple. One of the first arguments in favor of RNA-based regulations is that sRNAs can be rapidly synthetized, requiring less cell resources compared to the protein, allowing them to ensure a rapid response to an external signal [13]. Their relatively short half-lives also allow a fast recovery after removal of the stimulus. This may explain why they are an advantage in fast adaptive responses to different stimuli [197]. Another advantage to include sRNAs in regulatory networks is their ability to cooperate with the protein regulatory factors acting at different regulatory levels [198]. For example, while the protein repressor inhibits the transcription by binding the specific DNA element, the sRNA contributes to further repression on post-transcriptional level by base-pairing the mRNAs still present in the cell. This cooperation is especially effective when the mRNA has a long half-life [198]. The participation of sRNA in regulatory circuits thus enables fine-tuning of target gene expression [198].

Like transcriptional regulatory proteins, sRNAs, in particular the trans-encoded sRNAs, often have multiple targets [199]. The regulation of a specific target with respect to another depends on the amount and ratio between the regulatory RNAs and target mRNA, as well as the affinity that the sRNA has for the mRNA. This results in a hierarchical regulation depending on the specific induction conditions [198]. It is important to consider that the sRNA can be degraded together with the target within a duplex, impacting the whole regulation network [200]. Moreover, especially in Gram-negative bacteria, the competition between different sRNAs for RNA-binding proteins like Hfq may alter their regulatory function [201]. sRNA can also be important actors in the cross talk between specific signaling networks. For example, MicA is able to repress the operon encoding PhoPQ TCS probably to repress the possible upregulation of OMPs during stress condition [195]. Finally, one of the specific aspects of regulation mediated by sRNA is the evolvability: new sRNA can quickly emerge and targets can be acquired or lost [13]. This characteristic allows them to rapidly adapt for a specific group of organisms in an environmental niche [13].

\section{Strategies to Identify TCS-Associated sRNAs}

\subsection{Global Approaches for sRNA Identification}

A combination of bioinformatics and experimental genomic approaches is largely used for the identification of sRNAs and their characterization. Integration of RNA-seq data with computational analysis led to the robust identification of a great number of potential sRNAs in many bacterial species (reviewed in [202-204]). Global approaches provide rich data requiring further targeted experimental validations for selected number of candidates. Northern blot and quantitative RT-PCR allow detection of new sRNAs and their expression profile analysis. In vitro gel mobility shift assays, sRNA-mRNA duplex stability and processing analysis, toeprinting assays, as well as plasmid-based reporter assays and compensatory mutational analysis are among powerful tools for sRNA target validation and mechanistic studies of sRNA-dependent control of target gene expression (reviewed in [205]).

Several recent reviews describe in detail the diversity of RNA-sequencing technologies developed for different aspects of regulatory RNA analysis $[203,206]$. Transcriptional start site (TSS) mapping by differential RNA-seq (dRNA-seq) or 5'-end RNA-seq, whole-transcript RNA-seq, small RNA sequencing (sRNA-seq), 
and Term-seq for 3'-end RNA mapping could be cited among the most powerful unbiased approaches for genome-wide sRNA identification [207-209]. These deep sequencing approaches have been successfully implemented for sRNA discovery in Gram-negative and Gram-positive bacterial pathogens including Helicobacter pylori [207], L. monocytogenes [210,211], P. aeruginosa [212,213], L. pneumophila [214], Agrobacterium tumefaciens [215], Mycobacterium tuberculosis [216], C. difficile [177], Corynebacterium glutamicum, C. jejuni [217], Agrobacterium fabrum [218], Streptococcus agalactiae [219], V. cholerae [220], S. aureus [221], E. faecalis [211], N. meningitidis [222], Leptospira interrogans [223], Acinetobacter baumannii [224], Streptococcus pyogenes [225], and S. pneumoniae [226].

The recently developed transcriptomic approach of dual RNA-seq is particularly suitable for the discovery of sRNAs contributing to virulence control in pathogenic bacteria [41]. Dual RNA-seq allows to simultaneously monitor the induction of host responses to infection and the bacterial sRNAs that shape the interactions of the pathogen with its host. This approach was originally developed for the analysis of cells infected with intracellular bacteria but has also been used more recently for extracellular pathogens. The application of dual RNA-seq to Salmonella infection of human cells identified the previously uncharacterized PinT as a highly up-regulated sRNA during infection within macrophages that serves as a timer for switching between the virulence programs of this pathogen [41].

Application of RNA-seq technologies to analyze bacterial secRNome provides promising perspectives to expand the role of sRNAs in host-pathogen interactions [227]. Secreted RNAs and RNAs in extracellular vesicles (membrane vesicles and OMVs) with potential regulatory function in host could be characterized in both Gram-negative and Gram-positive bacteria, including recent examples in P. aeruginosa and L. monocytogenes [79,228]. Interestingly, Rli32, one of these sRNAs that have been identified as potential inducers of type I interferons IFN response during L. monocytogenes infection is part of the VirR/VirS and Agr quorum sensing regulons [79,229].

Many sRNAs act in concert with protein partners such as the RNA chaperone proteins Hfq and ProQ, facilitating base-pairing of sRNAs with their targets [230] or ribonucleases mediating their regulatory actions [231]. A specific class of sRNA regulators functions through sequestration of a regulatory protein such as the CsrA pleiotropic regulator [232]. Global identification of RNA ligands associated with RNA-binding proteins represents another largely used genomic strategy for sRNA discovery (reviewed in [203]). These global approaches include RNA immunoprecipitation followed by RNA-seq (RIP-seq) or (CLIP-seq) including an UV cross-linking step to covalently link protein-RNA interactions, RNA Interaction by Ligation and sequencing (RIL-seq), Cross-linking, Ligation, and Sequencing of Hybrids (CLASH) or Gradient profiling by sequencing (Grad-seq). When these approaches include an RNA-RNA ligation step, they lead to sRNAs direct target identification (see below).

In silico analyses help to predict both new sRNAs and potential sRNA targets. Bioinformatics predictions of new sRNAs are generally based on comparative genomics, RNA secondary structure analysis, and in silico searches for promoters and Rho-independent terminators associated with intergenic regions or located in antisense orientation to annotated genes in bacterial genomes [233]. Several programs are available for sRNA target predictions including TargetRNA, IntaRNA, CopraRNA, sTarPicker, RNAhybrid, and RNADuplex that can be used individually or in combination (reviewed in [234,235]).

Experimental validation of in silico predicted sRNA targets is required since these bioinformatics analyses usually lead to a large number of potential targets with a substantial proportion of false positive predictions [234]. Direct sRNA target identification still remains a challenging task, but several new experimental approaches have been recently developed for unbiased sRNA target discovery (reviewed in [206]). Among them, MS2-affinity purification coupled with RNA sequencing (MAPS) [236,237] allows sensitive detection of direct sRNA targets by base-pairing with an sRNA of interest, while RIL-seq [238] and CLASH [239] are used for global sRNA-RNA interaction analysis and rely on the association of sRNA-target pairs with RNA-binding proteins.

\subsection{Specific Approaches Adapted for TCS-Associated sRNAs}

Specific strategies have also been implemented for the identification of sRNAs related to TCS. In silico approaches are valuable for the prediction of TCS regulators involved in the regulation of sRNA expression. For example, an in silico search for the presence of a consensus sequence recognized by the specific response regulator CiaR identified several sRNAs genes as members of the CiaRH TCS regulon in S. pneumoniae [161]. A further study combined the sRNA target prediction with experimental validations to define the CiaRH-dependent 
csRNA targets [171]. Functional enrichment represents a powerful computational approach to specify the pathways targeted by sRNAs. Interestingly, such approach placed TCS as an enriched category of genes targeted by cis-encoded sRNAs in M. tuberculosis [216].

In C. perfringens, new members of the VirR/VirS TCS regulon have been discovered by a differential display method [97]. Screening of 1200 plasmids from a random chromosome library with cDNA probes from a virR mutant and wild-type strain led to the identification of VR-RNA as a secondary regulator in the VirR/VirS-dependent cascade controlling toxin production in this pathogen $[94,95,97]$. Two additional regulatory RNAs, VirT and VirU, were later discovered as direct VirR targets by in silico searches in C. perfringens genome sequence for the presence of the VirR box motif [240].

Global transcriptome analysis remains a tool of choice to define the regulons of transcriptional regulators [241]. Its application to comparative analysis of mutants inactivated for TCS response regulators can be combined with direct target identification by in silico or experimental chromatin immunoprecipitation followed by high-throughput sequencing (ChIP-seq) approaches to specify the regulatory cascades related to a given TCS. Integration of ChIP-seq results with RNA-seq data led to the discovery of the Mcr7 sRNA as a major PhoP target in M. tuberculosis, thus establishing a link between the PhoPR TCS, essential for virulence in this pathogen, and the downstream functions necessary for successful infection of the host [80]. Mcr7 was shown to modulate the Twin Arginine Translocation (Tat) protein secretion system involved in secretion of the immunodominant antigen Ag85 complex and the BlaC beta-lactamase in M. tuberculosis.

To broaden sRNA identification in S. pneumoniae, mutants of genes encoding the response regulator of three major TCSs: GRR, CbpR, and VncR have been analyzed by RNA-seq of small transcript-enriched fractions [242]. This study also used global pathogenesis profiling by Tn-seq focusing on the relative fitness level of sRNAs mutants in different infection sites in the host during infection to evaluate the contribution of sRNAs to pathogenesis. Transposon mutagenesis can also be used to discover new regulators of a given gene. For example, a forward genetic screen using a reporter gene fusion led to the identification of the KinB-AlgB TCS controlling CRISPR-Cas in $P$. aeruginosa [64].

The sequence-specific target recognition by sRNA of various functional classes involves a so-called "seed" region that is generally conserved among functional homologs of riboregulators [5]. The seed region is usually defined by sequence conservation analysis and mutational exchange for functional relevance. A novel sRNA-based approach has recently been developed to test the in vivo relevance of the conserved seed sequence under stress conditions [121]. Such seed sequences have been identified in ESR-regulated RNAs, RybB in E. coli and its functional homologues MicV and VrrA in V. cholerae. A library of synthetic sRNA regulators with randomized base-pairing region was first constructed and laboratory selection experiments for sRNA variants providing improved stress resistance were then performed. High-throughput sequencing of selected variants revealed that the seed-pairing domain of ESR-regulated sRNAs is strongly enriched among sRNAs identified under membrane-damaging conditions [121]. This strategy could be used for screening of complex bacterial phenotypes by using synthetic sRNA libraries and for the identification of the most efficient sRNA sequences for gene expression control and further applications.

\section{Antimicrobial Strategies Related with TCS and Associated sRNAs}

Broad-spectrum antibiotics have revolutionized the medicine and saved many lives. While they are still indispensable drugs today to fight against bacterial infections, important problems arose from their massive use. One of the direct consequences is the spreading of multiple drug-resistant (MDR) bacteria, such as methicillin-resistant S. aureus, that represent a critical problem for public health [243,244]. Moreover, the perturbation in the microbial composition of human microbiota caused by broad-spectrum antibiotics is associated with many diseases [245]. Another aspect to consider is that infections caused by major pathogens are difficult to treat with conventional antibiotics because of specific resistance mechanisms related with their infection life cycle. This includes, in the case of $C$. difficile, the differentiation into spores, which are intrinsically resistant to antibiotics [180], or the acquisition of antibiotic resistances through HGT in many pathogens [246,247]. There is therefore an urgent need to broaden the repertoire of new antibiotic targets and to find species-specific antimicrobial strategies. Because of their important roles in regulating virulence factors and genes for antibiotic resistance 
in major human pathogens, TCSs and sRNA-regulated transcripts are ascendant targets for new antimicrobial strategies. In higher eukaryotes, the signal transduction systems are generally based on serine, threonine and tyrosine phosphorylation, while the bacterial signaling systems imply histidine phosphorylation. These differences encourage the research on selective inhibitors of bacterial TCS [248,249]. For example, the small molecule LED209, identified by high-throughput screenings, inhibits the activation of the HK component QseC, comprised in the QseCB TCS, by AI-3 in different Gram-negative pathogenic bacteria. This inhibition impacts bacterial pathogenicity in vitro and in vivo but not cell growth [250]. Because of their function to sense the host conditions, TCSs together with transcriptional regulators are central actors in the design of engineered probiotics [251,252]. As a proof of concept to treat bacterial infection, the probiotic E. coli Nissle has been engineered to sense tetrathionate, a molecule produced in the inflamed gut during Salmonella infection, through the TtrS/R TCS. In response to this signal, E. coli secretes an antimicrobial peptide, Microcin H47, that inhibits Salmonella growth [253].

Moreover, the ability of sRNAs to silence gene expression has led to the development of a new antimicrobial strategy based on short antisense oligonucleotides (ASOs). The RNA-targeted therapeutics in the form of ASOs are a seductive treatment to cure human diseases including bacterial infections. While commercialized antisense therapy to treat diseases such as Cytomegalovirus (CMV) Retinitis, Homozygous Familial Hypercholesterolaemia (HoFH) and Spinal muscular atrophy (SMA) (complete list in review [254]) already exist, there are no approved RNA-targeted antimicrobials to cure bacterial infections. With the characterization of novel sRNAs important for the pathogenesis in bacteria, this strategy seems more plausible in the future. The increasing knowledge on the molecular mechanisms of natural trans-encoded RNA action in gene silencing by base-pairing led to a design of antisense antimicrobial therapeutics able to silence expression of bacterial essential genes [255]. To treat the skin infections caused by S. aureus, the ASO called CPP-PMO has been designed to target the mRNA of the essential gene gyr $A$. When administrated ectopically on skin wound in mice, the CPP-PMO reduces the viability of $S$. aureus [256]. Targeting virulence genes with ASO is an appealing approach to develop a new class of antimicrobials especially for MDR bacteria. Converting MDR bacteria to drug hyper susceptible cells is a potential approach to fight against MDR infection. It has been recently shown that the overexpression of the sRNA AS1974 in clinical isolates of MDR P. aeruginosa induces drug hyper susceptibility [257].

Beside the tempting perspective of developing RNA-targeted ASOs as new species-specific antibiotics, three main concerns derive from the use of RNA. First, RNA molecules are too unstable to be administrated as drugs. Nevertheless, existing chemical classes of modified nucleic acids with improved stability and nuclease resistance may be used to tackle this issue [255]. Second, the uptake of such molecules is difficult, so the ASOs are usually short and carry a cell-penetrating peptide (CPP) [258]. Third, ASOs usually sequester the RBS of an mRNA. Because RBS is a low complexity zone, off-targeting effects may be observed in other bacteria with similar RBS, thus compromising the killing specificity [259]. Rapidly accumulating knowledge on the "seed" regions as essential determinants for specific recognition by sRNAs of their targets could help to increase the specificity of programmable RNA-based antimicrobials [5]. New ideas have recently emerged suggesting the use of genes regulated by the sRNA, regulatory RNAs themselves and their protein interaction partners (e.g., Hfq or CsrA), as novel drug targets due to their contribution to antibiotics response and resistance (see reviews $[131,260,261]$ ). Interestingly, an inhibitor peptide (RI20) of Hfq-sRNA interactions has been identified in E. coli that inhibits Hfq function, increasing the susceptibility of E. coli to antibiotics [262].

Retargeting CRISPR-Cas system against pathogens has a great potential for development of programmable antimicrobials. CRISPR RNAs could be easily designed to target specific sequences in genes related to virulence of pathogenic strains. Delivery of engineered CRISPR-Cas system components using phages or phagemids has been suggested as an interesting therapeutic perspective for selective removal of bacterial pathogens and precise microbiome composition alteration [263]. On the other hand, endogenous CRISPR-Cas systems represent an important obstacle for development of alternative antimicrobial strategies based on phages. The discovery of quorum sensing control of CRISPR-Cas adaptive immunity system opens new therapeutic perspectives to suppress CRISPR function for medical applications combining phage therapy with quorum-sensing inhibitors [158,264].

Riboswitches have recently emerged as possible targets for the development of alternative antimicrobial approaches (reviewed in $[265,266]$ ). In C. difficile, a great number of riboswitches has been identified $[9,177]$, including c-di-GMP-responsive riboswitches important for virulence control $[267,268]$. Widespread use of 
riboswitches to control essential metabolic pathways motivated the research of ligand analogs with bactericidal activity. For example, a potential of guanine analogs targeting guanine-sensing riboswitches to inhibit $C$. difficile growth has been evaluated [269]. Similar strategies appear promising for the development of antimicrobials against S. aureus and other Gram-positive bacteria [270,271]. An efficient protection against $C$. difficile infection has recently been reported in mice for a riboflavin analog binding flavin mononucleotide FMN riboswitch without inhibiting normal cecal flora [272].

Another emerging application of sRNAs is their ability to be secreted in the extracellular space to modulate the immunity of the host [227]. Future characterization of secRNome of major pathogens will shed a new light on the role of sRNAs in host-pathogen interactions. The recent discovery of Rli32 sRNA inducing interferon response during L. monocytogenes infection illustrates well this yet unexplored regulatory potential [79]. This new field of research could suggest new ways to transport RNA inside the host and new possibilities for the modulation of host immune system.

\section{Conclusions}

Regulatory sRNAs have recently emerged as important components of regulatory networks controlling gene expression in bacterial pathogens. New technological developments provided powerful tools to study these regulatory processes. Multiple interconnections with signal transduction pathways have been revealed that ensure adequate responses to changing environments and survival of pathogens inside the host. New findings in this emerging field of RNA-based host-pathogen crosstalk could be anticipated in the near future. Accumulating knowledge on the molecular mechanisms involved in these adaptive responses and interactions of pathogens with their hosts paves the way for the development of new antimicrobial strategies as a challenging task for coming years. Deciphering molecular details of RNA-based control of gene expression in bacterial pathogens constitutes an essential step for harnessing these yet poorly explored powerful mechanisms in the future for specific therapeutic and epidemiological applications.

Author Contributions: E.P.; writing-original draft preparation, J.P. and O.S.; writing-review and editing. All authors have read and agreed to the published version of the manuscript.

Funding: This research was funded by Agence Nationale de la Recherche (“CloSTARn”, ANR-13-JSV3-0005-01), the Institut Universitaire de France, the University Paris-Saclay, the Institute for Integrative Biology of the Cell, the DIM-1HEALTH regional Ile de France program (LSP grant no. 164466), the Centre National de la Recherche Scientifique (CNRS-RFBR PRC 2019 grant no. 288426).

Acknowledgments: The authors apologize to the colleagues whose work could not be cited owing to space limitations.

Conflicts of Interest: The authors declare no conflict of interest.

\section{References}

1. Mitchell, A.; Romano, G.H.; Groisman, B.; Yona, A.; Dekel, E.; Kupiec, M.; Dahan, O.; Pilpel, Y. Adaptive prediction of environmental changes by microorganisms. Nature 2009, 460, 220-224. [CrossRef] [PubMed]

2. Hibbing, M.E.; Fuqua, C.; Parsek, M.R.; Peterson, S.B. Bacterial competition: Surviving and thriving in the microbial jungle. Nat. Rev. Microbiol. 2010, 8, 15-25. [CrossRef] [PubMed]

3. Bleuven, C.; Landry, C.R. Molecular and cellular bases of adaptation to a changing environment in microorganisms. Proc. Biol. Sci. 2016, 283. [CrossRef]

4. Wagner, E.G.H.; Romby, P. Small RNAs in bacteria and archaea: Who they are, what they do, and how they do it. Adv. Genet. 2015, 90, 133-208. [CrossRef] [PubMed]

5. Gorski, S.A.; Vogel, J.; Doudna, J.A. RNA-based recognition and targeting: Sowing the seeds of specificity. Nat. Rev. Mol. Cell Biol. 2017, 18, 215-228. [CrossRef] [PubMed]

6. Fabian, M.R.; Sonenberg, N.; Filipowicz, W. Regulation of mRNA Translation and Stability by microRNAs. Annu. Rev. Biochem. 2010, 79, 351-379. [CrossRef] [PubMed]

7. Waters, L.S.; Storz, G. Regulatory RNAs in bacteria. Cell 2009, 136, 615-628. [CrossRef] [PubMed]

8. Oliva, G.; Sahr, T.; Buchrieser, C. Small RNAs, 5' UTR elements and RNA-binding proteins in intracellular bacteria: Impact on metabolism and virulence. FEMS Microbiol. Rev. 2015, 39, 331-349. [CrossRef] [PubMed] 
9. Soutourina, O. RNA-based control mechanisms of Clostridium difficile. Curr. Opin. Microbiol. 2017, 36, 62-68. [CrossRef]

10. Storz, G.; Vogel, J.; Wassarman, K.M. Regulation by Small RNAs in Bacteria: Expanding Frontiers. Mol. Cell 2011, 43, 880-891. [CrossRef]

11. Smirnov, A.; Wang, C.; Drewry, L.L.; Vogel, J. Molecular mechanism of mRNA repression in trans by a ProQ-dependent small RNA. EMBO J. 2017, 36, 1029-1045. [CrossRef]

12. Romby, P.; Charpentier, E. An overview of RNAs with regulatory functions in gram-positive bacteria. Cell. Mol. Life Sci. 2010, 67, 217-237. [CrossRef]

13. Brosse, A.; Guillier, M. Bacterial Small RNAs in Mixed Regulatory Networks. Microbiol. Spectr. $2018,6$. [CrossRef]

14. Göpel, Y.; Görke, B. Rewiring two-component signal transduction with small RNAs. Curr. Opin. Microbiol. 2012, 15, 132-139. [CrossRef]

15. Mandin, P.; Guillier, M. Expanding control in bacteria: Interplay between small RNAs and transcriptional regulators to control gene expression. Curr. Opin. Microbiol. 2013, 16, 125-132. [CrossRef]

16. Chakravarty, S.; Massé, E. RNA-Dependent Regulation of Virulence in Pathogenic Bacteria. Front. Cell. Infect. Microbiol. 2019, 9. [CrossRef] [PubMed]

17. Hews, C.L.; Cho, T.; Rowley, G.; Raivio, T.L. Maintaining Integrity Under Stress: Envelope Stress Response Regulation of Pathogenesis in Gram-Negative Bacteria. Front. Cell. Infect. Microbiol. 2019, 9. [CrossRef]

18. Pucciarelli, M.G.; García-del Portillo, F. Within-Host Envelope Remodelling and its Impact in Bacterial Pathogen Recognition. Curr. Issues Mol. Biol. 2018, 25, 43-60. [CrossRef]

19. Munita, J.M.; Arias, C.A. Mechanisms of Antibiotic Resistance. Microbiol. Spectr. 2016, 4. [CrossRef]

20. Klein, G.; Raina, S. Small regulatory bacterial RNAs regulating the envelope stress response. Biochem. Soc. Trans. 2017, 45, 417-425. [CrossRef] [PubMed]

21. Kill, K.; Binnewies, T.T.; Sicheritz-Pontén, T.; Willenbrock, H.; Hallin, P.F.; Wassenaar, T.M.; Ussery, D.W. Genome update: Sigma factors in 240 bacterial genomes. Microbiology 2005, 151, 3147-3150. [CrossRef] [PubMed]

22. Gao, R.; Stock, A.M. Biological Insights from Structures of Two-Component Proteins. Annu. Rev. Microbiol. 2009, 63, 133-154. [CrossRef] [PubMed]

23. Groisman, E.A. Feedback Control of Two-Component Regulatory Systems. Annu. Rev. Microbiol. 2016, 70, 103-124. [CrossRef]

24. Alm, E.; Huang, K.; Arkin, A. The Evolution of Two-Component Systems in Bacteria Reveals Different Strategies for Niche Adaptation. PLoS Comput. Biol. 2006, 2. [CrossRef] [PubMed]

25. Grabowicz, M.; Silhavy, T.J. Envelope stress responses: An interconnected safety net. Trends Biochem. Sci. 2017, 42, 232-242. [CrossRef] [PubMed]

26. Chao, Y.; Vogel, J. A 3' UTR-Derived Small RNA Provides the Regulatory Noncoding Arm of the Inner Membrane Stress Response. Mol. Cell 2016, 61, 352-363. [CrossRef]

27. Grabowicz, M.; Koren, D.; Silhavy, T.J. The CpxQ sRNA Negatively Regulates Skp to Prevent Mistargeting of $\beta$-Barrel Outer Membrane Proteins into the Cytoplasmic Membrane. mBio 2016, 7. [CrossRef]

28. Vogt, S.L.; Evans, A.D.; Guest, R.L.; Raivio, T.L. The Cpx Envelope Stress Response Regulates and Is Regulated by Small Noncoding RNAs. J. Bacteriol. 2014, 196, 4229-4238. [CrossRef]

29. De Lay, N.; Gottesman, S. The Crp-activated small noncoding regulatory RNA CyaR (RyeE) links nutritional status to group behavior. J. Bacteriol. 2009, 191, 461-476. [CrossRef]

30. Lalaouna, D.; Prévost, K.; Laliberté, G.; Houé, V.; Massé, E. Contrasting silencing mechanisms of the same target mRNA by two regulatory RNAs in Escherichia coli. Nucleic Acids Res. 2018, 46, 2600-2612. [CrossRef]

31. Guillier, M.; Gottesman, S. Remodelling of the Escherichia coli outer membrane by two small regulatory RNAs. Mol. Microbiol. 2006, 59, 231-247. [CrossRef]

32. Guillier, M.; Gottesman, S. The $5^{\prime}$ end of two redundant sRNAs is involved in the regulation of multiple targets, including their own regulator. Nucleic Acids Res. 2008, 36, 6781-6794. [CrossRef] [PubMed]

33. Holmqvist, E.; Reimegård, J.; Sterk, M.; Grantcharova, N.; Römling, U.; Wagner, E.G.H. Two antisense RNAs target the transcriptional regulator CsgD to inhibit curli synthesis. EMBO J. 2010, 29, 1840-1850. [CrossRef] [PubMed]

34. De Lay, N.; Gottesman, S. A complex network of small non-coding RNAs regulate motility in Escherichia coli. Mol. Microbiol. 2012, 86, 524-538. [CrossRef] [PubMed] 
35. Brosse, A.; Korobeinikova, A.; Gottesman, S.; Guillier, M. Unexpected properties of sRNA promoters allow feedback control via regulation of a two-component system. Nucleic Acids Res. 2016, 44, 9650-9666. [CrossRef] [PubMed]

36. Andersen, J.; Delihas, N. micF RNA binds to the 5' end of ompF mRNA and to a protein from Escherichia coli. Biochemistry 1990, 29, 9249-9256. [CrossRef]

37. Holmqvist, E.; Unoson, C.; Reimegård, J.; Wagner, E.G.H. A mixed double negative feedback loop between the sRNA MicF and the global regulator Lrp. Mol. Microbiol. 2012, 84, 414-427. [CrossRef]

38. Moon, K.; Gottesman, S. A PhoQ/P-Regulated small RNA Regulates Sensitivity of Escherichia coli to Antimicrobial Peptides. Mol. Microbiol. 2009, 74, 1314-1330. [CrossRef]

39. Lee, H.-J.; Gottesman, S. sRNA roles in regulating transcriptional regulators: Lrp and SoxS regulation by sRNAs. Nucleic Acids Res. 2016, 44, 6907-6923. [CrossRef]

40. Lee, E.-J.; Groisman, E.A. An antisense RNA that governs the expression kinetics of a multifunctional virulence gene. Mol. Microbiol. 2010, 76, 1020-1033. [CrossRef]

41. Westermann, A.J.; Förstner, K.U.; Amman, F.; Barquist, L.; Chao, Y.; Schulte, L.N.; Müller, L.; Reinhardt, R.; Stadler, P.F.; Vogel, J. Dual RNA-seq unveils noncoding RNA functions in host-pathogen interactions. Nature 2016, 529, 496-501. [CrossRef] [PubMed]

42. Kim, K.; Palmer, A.D.; Vanderpool, C.K.; Slauch, J.M. The Small RNA PinT Contributes to PhoP-Mediated Regulation of the Salmonella Pathogenicity Island 1 Type III Secretion System in Salmonella enterica Serovar Typhimurium. J. Bacteriol. 2019, 201. [CrossRef] [PubMed]

43. Palmer, A.D.; Kim, K.; Slauch, J.M. PhoP-Mediated Repression of the SPI1 Type 3 Secretion System in Salmonella enterica Serovar Typhimurium. J. Bacteriol. 2019, 201. [CrossRef] [PubMed]

44. Majdalani, N.; Chen, S.; Murrow, J.; St John, K.; Gottesman, S. Regulation of RpoS by a novel small RNA: The characterization of RprA. Mol. Microbiol. 2001, 39, 1382-1394. [CrossRef]

45. Guo, X.-P.; Sun, Y.-C. New Insights into the Non-orthodox Two Component Rcs Phosphorelay System. Front. Microbiol. 2017, 8. [CrossRef]

46. Latasa, C.; García, B.; Echeverz, M.; Toledo-Arana, A.; Valle, J.; Campoy, S.; García-del Portillo, F.; Solano, C.; Lasa, I. Salmonella Biofilm Development Depends on the Phosphorylation Status of RcsB. J. Bacteriol. 2012, 194, 3708-3722. [CrossRef]

47. Urban, J.H.; Vogel, J. Two Seemingly Homologous Noncoding RNAs Act Hierarchically to Activate $g \mathrm{lmS}$ mRNA Translation. PLoS Biol. 2008, 6, e64. [CrossRef]

48. Reichenbach, B.; Göpel, Y.; Görke, B. Dual control by perfectly overlapping sigma 54- and sigma 70promoters adjusts small RNA GlmY expression to different environmental signals. Mol. Microbiol. 2009, 74, 1054-1070. [CrossRef]

49. Gruber, C.C.; Sperandio, V. Global Analysis of Posttranscriptional Regulation by GlmY and GlmZ in Enterohemorrhagic Escherichia coli O157:H7. Infect Immun. 2015, 83, 1286-1295. [CrossRef]

50. Reading, N.C.; Rasko, D.A.; Torres, A.G.; Sperandio, V. The two-component system QseEF and the membrane protein QseG link adrenergic and stress sensing to bacterial pathogenesis. Proc. Natl. Acad. Sci. USA 2009, 106, 5889-5894. [CrossRef]

51. Gruber, C.C.; Sperandio, V. Posttranscriptional control of microbe-induced rearrangement of host cell actin. mBio 2014, 5, e01025-01013. [CrossRef] [PubMed]

52. Mandin, P.; Gottesman, S. Integrating anaerobic/aerobic sensing and the general stress response through the ArcZ small RNA. EMBO J. 2010, 29, 3094-3107. [CrossRef]

53. Wen, Y.; Feng, J.; Sachs, G. Helicobacter pylori 5'ureB-sRNA, a cis-Encoded Antisense Small RNA, Negatively Regulates ure $A B$ Expression by Transcription Termination. J. Bacteriol. 2013, 195, 444-452. [CrossRef] [PubMed]

54. Bejerano-Sagie, M.; Xavier, K.B. The role of small RNAs in quorum sensing. Curr. Opin. Microbiol. 2007, 10, 189-198. [CrossRef]

55. Lenz, D.H.; Mok, K.C.; Lilley, B.N.; Kulkarni, R.V.; Wingreen, N.S.; Bassler, B.L. The small RNA chaperone Hfq and multiple small RNAs control quorum sensing in Vibrio harveyi and Vibrio cholerae. Cell 2004, 118, 69-82. [CrossRef]

56. Shao, Y.; Bassler, B.L. Quorum regulatory small RNAs repress type VI secretion in Vibrio cholerae. Mol. Microbiol. 2014, 92, 921-930. [CrossRef] 
57. Rutherford, S.T.; van Kessel, J.C.; Shao, Y.; Bassler, B.L. AphA and LuxR/HapR reciprocally control quorum sensing in vibrios. Genes Dev. 2011, 25, 397-408. [CrossRef]

58. Xi, D.; Li, Y.; Yan, J.; Li, Y.; Wang, X.; Cao, B. Small RNA coaR contributes to intestinal colonization in Vibrio cholerae via the two-component system EnvZ/OmpR. Environ. Microbiol. 2019. [CrossRef]

59. Peterson, K.M.; Gellings, P.S. Multiple intraintestinal signals coordinate the regulation of Vibrio cholerae virulence determinants. Pathog. Dis. 2018, 76. [CrossRef]

60. Sonnleitner, E.; Abdou, L.; Haas, D. Small RNA as global regulator of carbon catabolite repression in Pseudomonas aeruginosa. Proc. Natl. Acad. Sci. USA 2009, 106, 21866-21871. [CrossRef] [PubMed]

61. Linares, J.F.; Moreno, R.; Fajardo, A.; Martínez-Solano, L.; Escalante, R.; Rojo, F.; Martínez, J.L. The global regulator Crc modulates metabolism, susceptibility to antibiotics and virulence in Pseudomonas aeruginosa. Environ. Microbiol. 2010, 12, 3196-3212. [CrossRef] [PubMed]

62. Wenner, N.; Maes, A.; Cotado-Sampayo, M.; Lapouge, K. NrsZ: A novel, processed, nitrogen-dependent, small non-coding RNA that regulates Pseudomonas aeruginosa PAO1 virulence. Environ. Microbiol. 2014, 16, 1053-1068. [CrossRef] [PubMed]

63. Tata, M.; Amman, F.; Pawar, V.; Wolfinger, M.T.; Weiss, S.; Häussler, S.; Bläsi, U. The Anaerobically Induced sRNA PaiI Affects Denitrification in Pseudomonas aeruginosa PA14. Front. Microbiol. 2017, 8. [CrossRef]

64. Borges, A.L.; Castro, B.; Govindarajan, S.; Solvik, T.; Escalante, V.; Bondy-Denomy, J. Bacterial alginate regulators and phage homologs repress CRISPR-Cas immunity. Nat. Microbiol. 2020, 5, 679-687. [CrossRef]

65. Liu, W.; Li, M.; Jiao, L.; Wang, P.; Yan, Y. PmrA/PmrB Two-Component System Regulation of lipA Expression in Pseudomonas aeruginosa PAO1. Front. Microbiol. 2017, 8, 2690. [CrossRef] [PubMed]

66. Zere, T.R.; Vakulskas, C.A.; Leng, Y.; Pannuri, A.; Potts, A.H.; Dias, R.; Tang, D.; Kolaczkowski, B.; Georgellis, D.; Ahmer, B.M.M.; et al. Genomic Targets and Features of BarA-UvrY (-SirA) Signal Transduction Systems. PLoS ONE 2015, 10, e0145035. [CrossRef]

67. Chavez, R.G.; Alvarez, A.F.; Romeo, T.; Georgellis, D. The physiological stimulus for the BarA sensor kinase. J. Bacteriol. 2010, 192, 2009-2012. [CrossRef]

68. Brencic, A.; McFarland, K.A.; McManus, H.R.; Castang, S.; Mogno, I.; Dove, S.L.; Lory, S. The GacS/GacA signal transduction system of Pseudomonas aeruginosa acts exclusively through its control over the transcription of the RsmY and RsmZ regulatory small RNAs. Mol. Microbiol. 2009, 73, 434-445. [CrossRef]

69. González, N.; Heeb, S.; Valverde, C.; Kay, E.; Reimmann, C.; Junier, T.; Haas, D. Genome-wide search reveals a novel GacA-regulated small RNA in Pseudomonas species. BMC Genomics 2008, 9, 167. [CrossRef]

70. Sahr, T.; Brüggemann, H.; Jules, M.; Lomma, M.; Albert-Weissenberger, C.; Cazalet, C.; Buchrieser, C. Two small ncRNAs jointly govern virulence and transmission in Legionella pneumophila. Mol. Microbiol. 2009, 72, 741-762. [CrossRef]

71. Lenz, D.H.; Miller, M.B.; Zhu, J.; Kulkarni, R.V.; Bassler, B.L. CsrA and three redundant small RNAs regulate quorum sensing in Vibrio cholerae. Mol. Microbiol. 2005, 58, 1186-1202. [CrossRef]

72. Sievers, S.; Sternkopf Lillebæk, E.M.; Jacobsen, K.; Lund, A.; Mollerup, M.S.; Nielsen, P.K.; Kallipolitis, B.H. A multicopy sRNA of Listeria monocytogenes regulates expression of the virulence adhesin LapB. Nucleic Acids Res. 2014, 42, 9383-9398. [CrossRef]

73. Reis, O.; Sousa, S.; Camejo, A.; Villiers, V.; Gouin, E.; Cossart, P.; Cabanes, D. LapB, a novel Listeria monocytogenes LPXTG surface adhesin, required for entry into eukaryotic cells and virulence. J. Infect. Dis. 2010, 202, 551-562. [CrossRef]

74. Ross, J.A.; Thorsing, M.; Lillebæk, E.M.S.; Teixeira Dos Santos, P.; Kallipolitis, B.H. The LhrC sRNAs control expression of T cell-stimulating antigen TcsA in Listeria monocytogenes by decreasing tcs A mRNA stability. RNA Biol. 2019, 16, 270-281. [CrossRef] [PubMed]

75. Sievers, S.; Lund, A.; Menendez-Gil, P.; Nielsen, A.; Storm Mollerup, M.; Lambert Nielsen, S.; Buch Larsson, P.; Borch-Jensen, J.; Johansson, J.; Kallipolitis, B.H. The multicopy sRNA LhrC controls expression of the oligopeptide-binding protein OppA in Listeria monocytogenes. RNA Biol. 2015, 12, 985-997. [CrossRef] [PubMed]

76. Dos Santos, P.T.; Menendez-Gil, P.; Sabharwal, D.; Christensen, J.-H.; Brunhede, M.Z.; Lillebæk, E.M.S.; Kallipolitis, B.H. The Small Regulatory RNAs LhrC1-5 Contribute to the Response of Listeria monocytogenes to Heme Toxicity. Front. Microbiol. 2018, 9, 599. [CrossRef] [PubMed] 
77. Mollerup, M.S.; Ross, J.A.; Helfer, A.-C.; Meistrup, K.; Romby, P.; Kallipolitis, B.H. Two novel members of the LhrC family of small RNAs in Listeria monocytogenes with overlapping regulatory functions but distinctive expression profiles. RNA Biol. 2016, 13, 895-915. [CrossRef]

78. Grubaugh, D.; Regeimbal, J.M.; Ghosh, P.; Zhou, Y.; Lauer, P.; Dubensky, T.W.; Higgins, D.E. The VirAB ABC Transporter Is Required for VirR Regulation of Listeria monocytogenes Virulence and Resistance to Nisin. Infect. Immun. 2018, 86. [CrossRef] [PubMed]

79. Frantz, R.; Teubner, L.; Schultze, T.; La Pietra, L.; Müller, C.; Gwozdzinski, K.; Pillich, H.; Hain, T.; Weber-Gerlach, M.; Panagiotidis, G.-D.; et al. The secRNome of Listeria monocytogenes Harbors Small Noncoding RNAs That Are Potent Inducers of Beta Interferon. mBio 2019, 10. [CrossRef] [PubMed]

80. Solans, L.; Gonzalo-Asensio, J.; Sala, C.; Benjak, A.; Uplekar, S.; Rougemont, J.; Guilhot, C.; Malaga, W.; Martín, C.; Cole, S.T. The PhoP-Dependent ncRNA Mcr7 Modulates the TAT Secretion System in Mycobacterium tuberculosis. PLoS Pathog. 2014, 10. [CrossRef]

81. Novick, R.P.; Ross, H.F.; Projan, S.J.; Kornblum, J.; Kreiswirth, B.; Moghazeh, S. Synthesis of staphylococcal virulence factors is controlled by a regulatory RNA molecule. EMBO J. 1993, 12, 3967-3975. [CrossRef]

82. Bronesky, D.; Wu, Z.; Marzi, S.; Walter, P.; Geissmann, T.; Moreau, K.; Vandenesch, F.; Caldelari, I.; Romby, P. Staphylococcus aureus RNAIII and Its Regulon Link Quorum Sensing, Stress Responses, Metabolic Adaptation, and Regulation of Virulence Gene Expression. Annu. Rev. Microbiol. 2016, 70, 299-316. [CrossRef] [PubMed]

83. Xue, T.; Zhang, X.; Sun, H.; Sun, B. ArtR, a novel sRNA of Staphylococcus aureus, regulates $\alpha$-toxin expression by targeting the 5' UTR of sarT mRNA. Med. Microbiol. Immunol. 2014, 203, 1-12. [CrossRef]

84. Durand, S.; Braun, F.; Lioliou, E.; Romilly, C.; Helfer, A.-C.; Kuhn, L.; Quittot, N.; Nicolas, P.; Romby, P.; Condon, C. A Nitric Oxide Regulated Small RNA Controls Expression of Genes Involved in Redox Homeostasis in Bacillus subtilis. PLoS Genet. 2015, 11, e1004957. [CrossRef]

85. Bohn, C.; Rigoulay, C.; Chabelskaya, S.; Sharma, C.M.; Marchais, A.; Skorski, P.; Borezée-Durant, E.; Barbet, R.; Jacquet, E.; Jacq, A.; et al. Experimental discovery of small RNAs in Staphylococcus aureus reveals a riboregulator of central metabolism. Nucleic Acids Res. 2010, 38, 6620-6636. [CrossRef] [PubMed]

86. Schoenfelder, S.M.K.; Lange, C.; Prakash, S.A.; Marincola, G.; Lerch, M.F.; Wencker, F.D.R.; Förstner, K.U.; Sharma, C.M.; Ziebuhr, W. The small non-coding RNA RsaE influences extracellular matrix composition in Staphylococcus epidermidis biofilm communities. PLoS Pathog. 2019, 15, e1007618. [CrossRef]

87. Rochat, T.; Bohn, C.; Morvan, C.; Le Lam, T.N.; Razvi, F.; Pain, A.; Toffano-Nioche, C.; Ponien, P.; Jacq, A.; Jacquet, E.; et al. The conserved regulatory RNA RsaE down-regulates the arginine degradation pathway in Staphylococcus aureus. Nucleic Acids Res. 2018, 46, 8803-8816. [CrossRef] [PubMed]

88. Liu, Z.; Treviño, J.; Ramirez-Peña, E.; Sumby, P. The small regulatory RNA FasX controls pilus expression and adherence in the human bacterial pathogen group A Streptococcus. Mol. Microbiol. 2012, 86, 140-154. [CrossRef]

89. Kreikemeyer, B.; Boyle, M.D.P.; Buttaro, B.A.; Heinemann, M.; Podbielski, A. Group A streptococcal growth phase-associated virulence factor regulation by a novel operon (Fas) with homologies to two-component-type regulators requires a small RNA molecule. Mol. Microbiol. 2001, 39, 392-406. [CrossRef]

90. Ramirez-Peña, E.; Treviño, J.; Liu, Z.; Perez, N.; Sumby, P. The group A Streptococcus small regulatory RNA FasX enhances streptokinase activity by increasing the stability of the ska mRNA transcript. Mol. Microbiol. 2010, 78, 1332-1347. [CrossRef] [PubMed]

91. Laux, A.; Sexauer, A.; Sivaselvarajah, D.; Kaysen, A.; Brückner, R. Control of competence by related non-coding csRNAs in Streptococcus pneumoniae R6. Front. Genet. 2015, 6. [CrossRef] [PubMed]

92. Roberts, S.A.; Scott, J.R. RivR and the small RNA RivX: The missing links between the CovR regulatory cascade and the Mga regulon. Mol. Microbiol. 2007, 66, 1506-1522. [CrossRef]

93. Cheung, J.K.; Awad, M.M.; McGowan, S.; Rood, J.I. Functional Analysis of the VirSR Phosphorelay from Clostridium perfringens. PLoS ONE 2009, 4, e5849. [CrossRef] [PubMed]

94. Shimizu, T.; Yaguchi, H.; Ohtani, K.; Banu, S.; Hayashi, H. Clostridial VirR/VirS regulon involves a regulatory RNA molecule for expression of toxins. Mol. Microbiol. 2002, 43, 257-265. [CrossRef]

95. Ohtani, K. Gene regulation by the VirS/VirR system in Clostridium perfringens. Anaerobe 2016, 41, 5-9. [CrossRef] [PubMed]

96. Obana, N.; Shirahama, Y.; Abe, K.; Nakamura, K. Stabilization of Clostridium perfringens collagenase mRNA by VR-RNA-dependent cleavage in 5' leader sequence. Mol. Microbiol. 2010, 77, 1416-1428. [CrossRef]

97. Banu, S.; Ohtani, K.; Yaguchi, H.; Swe, T.; Cole, S.T.; Hayashi, H.; Shimizu, T. Identification of novel VirR/VirS-regulated genes in Clostridium perfringens. Mol. Microbiol. 2000, 35, 854-864. [CrossRef] 
98. Fang, F.C.; Frawley, E.R.; Tapscott, T.; Vazquez-Torres, A. Bacterial Stress Responses during Host Infection. Cell Host Microbe 2016, 20, 133-143. [CrossRef]

99. Kazmierczak, M.J.; Wiedmann, M.; Boor, K.J. Alternative sigma factors and their roles in bacterial virulence. Microbiol. Mol. Biol. Rev. MMBR 2005, 69, 527-543. [CrossRef]

100. Guldimann, C.; Boor, K.J.; Wiedmann, M.; Guariglia-Oropeza, V. Resilience in the Face of Uncertainty: Sigma Factor B Fine-Tunes Gene Expression to Support Homeostasis in Gram-Positive Bacteria. Appl. Environ. Microbiol. 2016, 82, 4456-4469. [CrossRef]

101. Geissmann, T.; Chevalier, C.; Cros, M.-J.; Boisset, S.; Fechter, P.; Noirot, C.; Schrenzel, J.; François, P.; Vandenesch, F.; Gaspin, C.; et al. A search for small noncoding RNAs in Staphylococcus aureus reveals a conserved sequence motif for regulation. Nucleic Acids Res. 2009, 37, 7239-7257. [CrossRef] [PubMed]

102. Romilly, C.; Lays, C.; Tomasini, A.; Caldelari, I.; Benito, Y.; Hammann, P.; Geissmann, T.; Boisset, S.; Romby, P.; Vandenesch, F. A non-coding RNA promotes bacterial persistence and decreases virulence by regulating a regulator in Staphylococcus aureus. PLoS Pathog. 2014, 10, e1003979. [CrossRef] [PubMed]

103. Tomasini, A.; Moreau, K.; Chicher, J.; Geissmann, T.; Vandenesch, F.; Romby, P.; Marzi, S.; Caldelari, I. The RNA targetome of Staphylococcus aureus non-coding RNA RsaA: Impact on cell surface properties and defense mechanisms. Nucleic Acids Res. 2017, 45, 6746-6760. [CrossRef] [PubMed]

104. Nielsen, J.S.; Olsen, A.S.; Bonde, M.; Valentin-Hansen, P.; Kallipolitis, B.H. Identification of a sigma B-dependent small noncoding RNA in Listeria monocytogenes. J. Bacteriol. 2008, 190, 6264-6270. [CrossRef]

105. Liu, Y.; Orsi, R.H.; Boor, K.J.; Wiedmann, M.; Guariglia-Oropeza, V. Home Alone: Elimination of All but One Alternative Sigma Factor in Listeria monocytogenes Allows Prediction of New Roles for $\sigma$ B. Front. Microbiol. 2017, 8, 1910. [CrossRef]

106. Mraheil, M.A.; Billion, A.; Mohamed, W.; Mukherjee, K.; Kuenne, C.; Pischimarov, J.; Krawitz, C.; Retey, J.; Hartsch, T.; Chakraborty, T.; et al. The intracellular sRNA transcriptome of Listeria monocytogenes during growth in macrophages. Nucleic Acids Res. 2011, 39, 4235-4248. [CrossRef]

107. Toledo-Arana, A.; Dussurget, O.; Nikitas, G.; Sesto, N.; Guet-Revillet, H.; Balestrino, D.; Loh, E.; Gripenland, J.; Tiensuu, T.; Vaitkevicius, K.; et al. The Listeria transcriptional landscape from saprophytism to virulence. Nature 2009, 459, 950-956. [CrossRef]

108. Gottesman, S. Trouble is coming: Signaling pathways that regulate general stress responses in bacteria. J. Biol. Chem. 2019, 294, 11685-11700. [CrossRef]

109. Rouvière, P.E.; De Las Peñas, A.; Mecsas, J.; Lu, C.Z.; Rudd, K.E.; Gross, C.A. rpoE, the gene encoding the second heat-shock sigma factor, sigma E, in Escherichia coli. EMBO J. 1995, 14, 1032-1042. [CrossRef]

110. Brooks, B.E.; Buchanan, S.K. Signaling mechanisms for activation of extracytoplasmic function (ECF) sigma factors. Biochim. Biophys. Acta 2008, 1778, 1930-1945. [CrossRef]

111. Mutalik, V.K.; Nonaka, G.; Ades, S.E.; Rhodius, V.A.; Gross, C.A. Promoter Strength Properties of the Complete Sigma E Regulon of Escherichia coli and Salmonella enterica. J. Bacteriol. 2009, 191, 7279-7287. [CrossRef]

112. Gogol, E.B.; Rhodius, V.A.; Papenfort, K.; Vogel, J.; Gross, C.A. Small RNAs endow a transcriptional activator with essential repressor functions for single-tier control of a global stress regulon. Proc. Natl. Acad. Sci. USA 2011, 108, 12875-12880. [CrossRef] [PubMed]

113. Johansen, J.; Rasmussen, A.A.; Overgaard, M.; Valentin-Hansen, P. Conserved small non-coding RNAs that belong to the sigmaE regulon: Role in down-regulation of outer membrane proteins. J. Mol. Biol. 2006, 364, 1-8. [CrossRef] [PubMed]

114. De Las Peñas, A.; Connolly, L.; Gross, C.A. SigmaE is an essential sigma factor in Escherichia coli. J. Bacteriol. 1997, 179, 6862-6864. [CrossRef] [PubMed]

115. Guo, M.S.; Updegrove, T.B.; Gogol, E.B.; Shabalina, S.A.; Gross, C.A.; Storz, G. MicL, a new oE-dependent sRNA, combats envelope stress by repressing synthesis of Lpp, the major outer membrane lipoprotein. Genes Dev. 2014, 28, 1620-1634. [CrossRef] [PubMed]

116. Song, T.; Mika, F.; Lindmark, B.; Liu, Z.; Schild, S.; Bishop, A.; Zhu, J.; Camilli, A.; Johansson, J.; Vogel, J.; et al. A new Vibrio cholerae sRNA modulates colonization and affects release of outer membrane vesicles. Mol. Microbiol. 2008, 70, 100-111. [CrossRef] [PubMed]

117. Ahmadi Badi, S.; Bruno, S.P.; Moshiri, A.; Tarashi, S.; Siadat, S.D.; Masotti, A. Small RNAs in Outer Membrane Vesicles and Their Function in Host-Microbe Interactions. Front. Microbiol. 2020, 11. [CrossRef] [PubMed]

118. Song, T.; Sabharwal, D.; Wai, S.N. VrrA mediates Hfq-dependent regulation of OmpT synthesis in Vibrio cholerae. J. Mol. Biol. 2010, 400, 682-688. [CrossRef] [PubMed] 
119. Song, T.; Sabharwal, D.; Gurung, J.M.; Cheng, A.T.; Sjöström, A.E.; Yildiz, F.H.; Uhlin, B.E.; Wai, S.N. Vibrio cholerae utilizes direct sRNA regulation in expression of a biofilm matrix protein. PLOS ONE 2014, 9, e101280. [CrossRef]

120. Sabharwal, D.; Song, T.; Papenfort, K.; Wai, S.N. The VrrA sRNA controls a stationary phase survival factor Vrp of Vibrio cholerae. RNA Biol. 2015, 12, 186-196. [CrossRef]

121. Peschek, N.; Hoyos, M.; Herzog, R.; Förstner, K.U.; Papenfort, K. A conserved RNA seed-pairing domain directs small RNA-mediated stress resistance in enterobacteria. EMBO J. 2019, 38, e101650. [CrossRef] [PubMed]

122. Dalebroux, Z.D.; Miller, S.I. Salmonellae PhoPQ regulation of the outer membrane to resist innate immunity. Curr. Opin. Microbiol. 2014, 17, 106-113. [CrossRef] [PubMed]

123. Flores-Kim, J.; Darwin, A.J. Regulation of bacterial virulence gene expression by cell envelope stress responses. Virulence 2015, 5, 835-851. [CrossRef] [PubMed]

124. Trimble, M.J.; Mlynárčik, P.; Kolář, M.; Hancock, R.E.W. Polymyxin: Alternative Mechanisms of Action and Resistance. Cold Spring Harb. Perspect. Med. 2016, 6. [CrossRef] [PubMed]

125. Peschel, A. How do bacteria resist human antimicrobial peptides? Trends Microbiol. 2002, 10, 179-186. [CrossRef]

126. Alix, E.; Blanc-Potard, A.-B. Peptide-assisted degradation of the Salmonella MgtC virulence factor. EMBO J. 2008, 27, 546-557. [CrossRef]

127. Ahmed, W.; Zheng, K.; Liu, Z.-F. Small Non-Coding RNAs: New Insights in Modulation of Host Immune Response by Intracellular Bacterial Pathogens. Front. Immunol. 2016, 7. [CrossRef]

128. Nikaido, H. Molecular Basis of Bacterial Outer Membrane Permeability Revisited. Microbiol. Mol. Biol. Rev. 2003, 67, 593-656. [CrossRef]

129. Nikaido, H.; Rosenberg, E.Y. Porin channels in Escherichia coli: Studies with liposomes reconstituted from purified proteins. J. Bacteriol. 1983, 153, 241-252. [CrossRef]

130. Kim, T.; Bak, G.; Lee, J.; Kim, K.-S. Systematic analysis of the role of bacterial Hfq-interacting sRNAs in the response to antibiotics. J. Antimicrob. Chemother. 2015, 70, 1659-1668. [CrossRef]

131. Felden, B.; Cattoir, V. Bacterial Adaptation to Antibiotics through Regulatory RNAs. Antimicrob. Agents Chemother. 2018, 62. [CrossRef]

132. Soutourina, O.A.; Bertin, P.N. Regulation cascade of flagellar expression in Gram-negative bacteria. FEMS Microbiol. Rev. 2003, 27, 505-523. [CrossRef]

133. Romilly, C.; Hoekzema, M.; Holmqvist, E.; Wagner, E.G.H. Small RNAs OmrA and OmrB promote class III flagellar gene expression by inhibiting the synthesis of anti-Sigma factor FlgM. RNA Biol. 2020, 17, 872-880. [CrossRef] [PubMed]

134. Van Puyvelde, S.; Steenackers, H.P.; Vanderleyden, J. Small RNAs regulating biofilm formation and outer membrane homeostasis. RNA Biol. 2013, 10, 185-191. [CrossRef]

135. Svenningsen, S.L. Small RNA-Based Regulation of Bacterial Quorum Sensing and Biofilm Formation. Microbiol. Spectr. 2018, 6. [CrossRef]

136. Rutherford, S.T.; Bassler, B.L. Bacterial quorum sensing: Its role in virulence and possibilities for its control. Cold Spring Harb. Perspect. Med. 2012, 2. [CrossRef]

137. Benito, Y.; Kolb, F.A.; Romby, P.; Lina, G.; Etienne, J.; Vandenesch, F. Probing the structure of RNAIII, the Staphylococcus aureus agr regulatory RNA, and identification of the RNA domain involved in repression of protein A expression. RNA 2000, 6, 668-679. [CrossRef]

138. Liu, Y.; Wu, N.; Dong, J.; Gao, Y.; Zhang, X.; Mu, C.; Shao, N.; Yang, G. Hfq Is a Global Regulator That Controls the Pathogenicity of Staphylococcus aureus. PLoS ONE 2010, 5. [CrossRef]

139. Felden, B.; Vandenesch, F.; Bouloc, P.; Romby, P. The Staphylococcus aureus RNome and its commitment to virulence. PLoS Pathog. 2011, 7, e1002006. [CrossRef]

140. Guillet, J.; Hallier, M.; Felden, B. Emerging Functions for the Staphylococcus aureus RNome. PLoS Pathog. 2013, 9, e1003767. [CrossRef]

141. Morfeldt, E.; Taylor, D.; von Gabain, A.; Arvidson, S. Activation of alpha-toxin translation in Staphylococcus aureus by the trans-encoded antisense RNA, RNAIII. EMBO J. 1995, 14, 4569-4577. [CrossRef] [PubMed]

142. Liu, Y.; Mu, C.; Ying, X.; Li, W.; Wu, N.; Dong, J.; Gao, Y.; Shao, N.; Fan, M.; Yang, G. RNAIII activates map expression by forming an RNA-RNA complex in Staphylococcus aureus. FEBS Lett. 2011, 585, 899-905. [CrossRef] [PubMed] 
143. Boisset, S.; Geissmann, T.; Huntzinger, E.; Fechter, P.; Bendridi, N.; Possedko, M.; Chevalier, C.; Helfer, A.C.; Benito, Y.; Jacquier, A.; et al. Staphylococcus aureus RNAIII coordinately represses the synthesis of virulence factors and the transcription regulator Rot by an antisense mechanism. Genes Dev. 2007, 21, 1353-1366. [CrossRef] [PubMed]

144. Traber, K.E.; Lee, E.; Benson, S.; Corrigan, R.; Cantera, M.; Shopsin, B.; Novick, R.P. agr function in clinical Staphylococcus aureus isolates. Microbiology 2008, 154, 2265-2274. [CrossRef]

145. Huntzinger, E.; Boisset, S.; Saveanu, C.; Benito, Y.; Geissmann, T.; Namane, A.; Lina, G.; Etienne, J.; Ehresmann, B.; Ehresmann, C.; et al. Staphylococcus aureus RNAIII and the endoribonuclease III coordinately regulate spa gene expression. EMBO J. 2005, 24, 824-835. [CrossRef]

146. Chabelskaya, S.; Bordeau, V.; Felden, B. Dual RNA regulatory control of a Staphylococcus aureus virulence factor. Nucleic Acids Res. 2014, 42, 4847-4858. [CrossRef]

147. Shopsin, B.; Drlica-Wagner, A.; Mathema, B.; Adhikari, R.P.; Kreiswirth, B.N.; Novick, R.P. Prevalence of $a g r$ dysfunction among colonizing Staphylococcus aureus strains. J. Infect. Dis. 2008, 198, 1171-1174. [CrossRef]

148. Shopsin, B.; Eaton, C.; Wasserman, G.A.; Mathema, B.; Adhikari, R.P.; Agolory, S.; Altman, D.R.; Holzman, R.S.; Kreiswirth, B.N.; Novick, R.P. Mutations in agr do not persist in natural populations of methicillin-resistant Staphylococcus aureus. J. Infect. Dis. 2010, 202, 1593-1599. [CrossRef]

149. Queck, S.Y.; Khan, B.A.; Wang, R.; Bach, T.-H.L.; Kretschmer, D.; Chen, L.; Kreiswirth, B.N.; Peschel, A.; Deleo, F.R.; Otto, M. Mobile genetic element-encoded cytolysin connects virulence to methicillin resistance in MRSA. PLoS Pathog. 2009, 5, e1000533. [CrossRef]

150. Kaito, C.; Saito, Y.; Ikuo, M.; Omae, Y.; Mao, H.; Nagano, G.; Fujiyuki, T.; Numata, S.; Han, X.; Obata, K.; et al. Mobile Genetic Element SCCmec-encoded psm-mec RNA Suppresses Translation of agrA and Attenuates MRSA Virulence. PLoS Pathog. 2013, 9, e1003269. [CrossRef]

151. Autret, N.; Raynaud, C.; Dubail, I.; Berche, P.; Charbit, A. Identification of the agr Locus of Listeria monocytogenes: Role in Bacterial Virulence. Infect. Immun. 2003, 71, 4463-4471. [CrossRef]

152. Martin, M.J.; Clare, S.; Goulding, D.; Faulds-Pain, A.; Barquist, L.; Browne, H.P.; Pettit, L.; Dougan, G.; Lawley, T.D.; Wren, B.W. The agr locus regulates virulence and colonization genes in Clostridium difficile 027. J. Bacteriol. 2013, 195, 3672-3681. [CrossRef]

153. Qin, X.; Singh, K.V.; Weinstock, G.M.; Murray, B.E. Effects of Enterococcus faecalis fsr Genes on Production of Gelatinase and a Serine Protease and Virulence. Infect. Immun. 2000, 68, 2579-2586. [CrossRef] [PubMed]

154. Cooksley, C.M.; Davis, I.J.; Winzer, K.; Chan, W.C.; Peck, M.W.; Minton, N.P. Regulation of Neurotoxin Production and Sporulation by a Putative agrBD Signaling System in Proteolytic Clostridium botulinum. Appl. Environ. Microbiol. 2010, 76, 4448-4460. [CrossRef]

155. Ohtani, K.; Yuan, Y.; Hassan, S.; Wang, R.; Wang, Y.; Shimizu, T. Virulence Gene Regulation by the agr System in Clostridium perfringens. J. Bacteriol. 2009, 191, 3919-3927. [CrossRef]

156. Bernheim, A.; Sorek, R. The pan-immune system of bacteria: Antiviral defence as a community resource. Nat. Rev. Microbiol. 2020, 18, 113-119. [CrossRef] [PubMed]

157. Patterson, A.G.; Jackson, S.A.; Taylor, C.; Evans, G.B.; Salmond, G.P.C.; Przybilski, R.; Staals, R.H.J.; Fineran, P.C. Quorum Sensing Controls Adaptive Immunity through the Regulation of Multiple CRISPR-Cas Systems. Mol. Cell 2016, 64, 1102-1108. [CrossRef] [PubMed]

158. Høyland-Kroghsbo, N.M.; Paczkowski, J.; Mukherjee, S.; Broniewski, J.; Westra, E.; Bondy-Denomy, J.; Bassler, B.L. Quorum sensing controls the Pseudomonas aeruginosa CRISPR-Cas adaptive immune system. Proc. Natl. Acad. Sci. USA 2017, 114, 131-135. [CrossRef]

159. Mion, S.; Plener, L.; Rémy, B.; Daudé, D.; Chabrière, É. Lactonase SsoPox modulates CRISPR-Cas expression in gram-negative proteobacteria using AHL-based quorum sensing systems. Res. Microbiol. 2019, 170, 296-299. [CrossRef] [PubMed]

160. Serbanescu, M.A.; Cordova, M.; Krastel, K.; Flick, R.; Beloglazova, N.; Latos, A.; Yakunin, A.F.; Senadheera, D.B.; Cvitkovitch, D.G. Role of the Streptococcus mutans CRISPR-Cas systems in immunity and cell physiology. J. Bacteriol. 2015, 197, 749-761. [CrossRef]

161. Marx, P.; Nuhn, M.; Kovács, M.; Hakenbeck, R.; Brückner, R. Identification of genes for small non-coding RNAs that belong to the regulon of the two-component regulatory system CiaRH in Streptococcus. BMC Genomics 2010, 11, 661. [CrossRef] [PubMed]

162. Høyland-Kroghsbo, N.M.; Muñoz, K.A.; Bassler, B.L. Temperature, by Controlling Growth Rate, Regulates CRISPR-Cas Activity in Pseudomonas aeruginosa. mBio 2018, 9. [CrossRef] [PubMed] 
163. Westra, E.R.; Buckling, A.; Fineran, P.C. CRISPR-Cas systems: Beyond adaptive immunity. Nat. Rev. Microbiol. 2014, 12, 317-326. [CrossRef] [PubMed]

164. Sampson, T.R.; Weiss, D.S. CRISPR-Cas systems: New players in gene regulation and bacterial physiology. Front. Cell. Infect. Microbiol. 2014, 4, 37. [CrossRef] [PubMed]

165. Sampson, T.R.; Saroj, S.D.; Llewellyn, A.C.; Tzeng, Y.-L.; Weiss, D.S. A CRISPR/Cas system mediates bacterial innate immune evasion and virulence. Nature 2013, 497, 254-257. [CrossRef]

166. Sesto, N.; Touchon, M.; Andrade, J.M.; Kondo, J.; Rocha, E.P.C.; Arraiano, C.M.; Archambaud, C.; Westhof, É.; Romby, P.; Cossart, P. A PNPase dependent CRISPR System in Listeria. PLoS Genet. 2014, 10, e1004065. [CrossRef]

167. Dugar, G.; Leenay, R.T.; Eisenbart, S.K.; Bischler, T.; Aul, B.U.; Beisel, C.L.; Sharma, C.M. CRISPR RNA-Dependent Binding and Cleavage of Endogenous RNAs by the Campylobacter jejuni Cas9. Mol. Cell. 2018, 69, 893-905.e7. [CrossRef]

168. Cui, L.; Wang, X.; Huang, D.; Zhao, Y.; Feng, J.; Lu, Q.; Pu, Q.; Wang, Y.; Cheng, G.; Wu, M.; et al. CRISPR-cas 3 of Salmonella Upregulates Bacterial Biofilm Formation and Virulence to Host Cells by Targeting Quorum-Sensing Systems. Pathogens 2020, 9, 53. [CrossRef]

169. Brantl, S.; Brückner, R. Small regulatory RNAs from low-GC Gram-positive bacteria. RNA Biol. 2014, 11, 443-456. [CrossRef]

170. Acebo, P.; Martin-Galiano, A.J.; Navarro, S.; Zaballos, A.; Amblar, M. Identification of 88 regulatory small RNAs in the TIGR4 strain of the human pathogen Streptococcus pneumoniae. RNA 2012, 18, 530-546. [CrossRef]

171. Schnorpfeil, A.; Kranz, M.; Kovács, M.; Kirsch, C.; Gartmann, J.; Brunner, I.; Bittmann, S.; Brückner, R. Target evaluation of the non-coding csRNAs reveals a link of the two-component regulatory system CiaRH to competence control in Streptococcus pneumoniae R6. Mol. Microbiol. 2013, 89, 334-349. [CrossRef] [PubMed]

172. Serganov, A.; Nudler, E. A decade of riboswitches. Cell 2013, 152, 17-24. [CrossRef]

173. McCown, P.J.; Corbino, K.A.; Stav, S.; Sherlock, M.E.; Breaker, R.R. Riboswitch diversity and distribution. RNA 2017, 23, 995-1011. [CrossRef] [PubMed]

174. Abduljalil, J.M. Bacterial riboswitches and RNA thermometers: Nature and contributions to pathogenesis. Non Coding RNA Res. 2018, 3, 54-63. [CrossRef] [PubMed]

175. Valentini, M.; Filloux, A. Multiple Roles of c-di-GMP Signaling in Bacterial Pathogenesis. Annu. Rev. Microbiol. 2019, 73, 387-406. [CrossRef]

176. Bordeleau, E.; Fortier, L.-C.; Malouin, F.; Burrus, V. c-di-GMP turn-over in Clostridium difficile is controlled by a plethora of diguanylate cyclases and phosphodiesterases. PLoS Genet. 2011, 7, e1002039. [CrossRef]

177. Soutourina, O.A.; Monot, M.; Boudry, P.; Saujet, L.; Pichon, C.; Sismeiro, O.; Semenova, E.; Severinov, K.; Le Bouguenec, C.; Coppée, J.-Y.; et al. Genome-wide identification of regulatory RNAs in the human pathogen Clostridium difficile. PLoS Genet. 2013, 9, e1003493. [CrossRef]

178. Sudarsan, N.; Lee, E.R.; Weinberg, Z.; Moy, R.H.; Kim, J.N.; Link, K.H.; Breaker, R.R. Riboswitches in eubacteria sense the second messenger cyclic di-GMP. Science 2008, 321, 411-413. [CrossRef]

179. Purcell, E.B.; McKee, R.W.; McBride, S.M.; Waters, C.M.; Tamayo, R. Cyclic diguanylate inversely regulates motility and aggregation in Clostridium difficile. J. Bacteriol. 2012, 194, 3307-3316. [CrossRef]

180. Smits, W.K.; Lyras, D.; Lacy, D.B.; Wilcox, M.H.; Kuijper, E.J. Clostridium difficile infection. Nat. Rev. Dis. Primers 2016, 2, 16020. [CrossRef]

181. Sekulovic, O.; Mathias Garrett, E.; Bourgeois, J.; Tamayo, R.; Shen, A.; Camilli, A. Genome-wide detection of conservative site-specific recombination in bacteria. PLoS Genet. 2018, 14, e1007332. [CrossRef] [PubMed]

182. Garrett, E.M.; Sekulovic, O.; Wetzel, D.; Jones, J.B.; Edwards, A.N.; Vargas-Cuebas, G.; McBride, S.M.; Tamayo, R. Phase variation of a signal transduction system controls Clostridioides difficile colony morphology, motility, and virulence. PLoS Biol. 2019, 17, e3000379. [CrossRef] [PubMed]

183. DebRoy, S.; Gebbie, M.; Ramesh, A.; Goodson, J.R.; Cruz, M.R.; van Hoof, A.; Winkler, W.C.; Garsin, D.A. Riboswitches. A riboswitch-containing sRNA controls gene expression by sequestration of a response regulator. Science 2014, 345, 937-940. [CrossRef] [PubMed]

184. Mellin, J.R.; Koutero, M.; Dar, D.; Nahori, M.-A.; Sorek, R.; Cossart, P. Riboswitches. Sequestration of a two-component response regulator by a riboswitch-regulated noncoding RNA. Science 2014, 345, 940-943. [CrossRef]

185. Shu, C.J.; Zhulin, I.B. ANTAR: An RNA-binding domain in transcription antitermination regulatory proteins. Trends Biochem. Sci. 2002, 27, 3-5. [CrossRef] 
186. Danger, J.L.; Makthal, N.; Kumaraswami, M.; Sumby, P. The FasX Small Regulatory RNA Negatively Regulates the Expression of Two Fibronectin-Binding Proteins in Group A Streptococcus. J. Bacteriol. 2015, 197, 3720-3730. [CrossRef]

187. Perez, N.; Treviño, J.; Liu, Z.; Ho, S.C.M.; Babitzke, P.; Sumby, P. A genome-wide analysis of small regulatory RNAs in the human pathogen group A Streptococcus. PLoS ONE 2009, 4, e7668. [CrossRef]

188. Danger, J.L.; Cao, T.N.; Cao, T.H.; Sarkar, P.; Treviño, J.; Pflughoeft, K.J.; Sumby, P. The small regulatory RNA FasX enhances group A Streptococcus virulence and inhibits pilus expression via serotype-specific targets. Mol. Microbiol. 2015, 96, 249-262. [CrossRef]

189. Dalton, T.L.; Collins, J.T.; Barnett, T.C.; Scott, J.R. RscA, a member of the MDR1 family of transporters, is repressed by CovR and required for growth of Streptococcus pyogenes under heat stress. J. Bacteriol. 2006, 188, 77-85. [CrossRef]

190. Roberts, S.A.; Churchward, G.G.; Scott, J.R. Unraveling the regulatory network in Streptococcus pyogenes: The global response regulator CovR represses rivR directly. J. Bacteriol. 2007, 189, 1459-1463. [CrossRef]

191. Treviño, J.; Liu, Z.; Cao, T.N.; Ramirez-Peña, E.; Sumby, P. RivR is a negative regulator of virulence factor expression in group A Streptococcus. Infect. Immun. 2013, 81, 364-372. [CrossRef] [PubMed]

192. King, A.N.; de Mets, F.; Brinsmade, S.R. Who's in control? Regulation of metabolism and pathogenesis in space and time. Curr. Opin. Microbiol. 2020, 55, 88-96. [CrossRef] [PubMed]

193. Mandin, P.; Gottesman, S. A genetic approach for finding small RNAs regulators of genes of interest identifies RybC as regulating the DpiA / DpiB two component system. Mol. Microbiol. 2009, 72, 551-565. [CrossRef] [PubMed]

194. Hao, Y.; Updegrove, T.B.; Livingston, N.N.; Storz, G. Protection against deleterious nitrogen compounds: Role of oS-dependent small RNAs encoded adjacent to sdiA. Nucleic Acids Res. 2016, 44, 6935-6948. [CrossRef]

195. Coornaert, A.; Lu, A.; Mandin, P.; Springer, M.; Gottesman, S.; Guillier, M. MicA sRNA links the PhoP regulon to cell envelope stress. Mol. Microbiol. 2010, 76, 467-479. [CrossRef]

196. Coornaert, A.; Chiaruttini, C.; Springer, M.; Guillier, M. Post-Transcriptional Control of the Escherichia coli PhoQ-PhoP Two-Component System by Multiple sRNAs Involves a Novel Pairing Region of GcvB. PLoS Genet. 2013, 9, e1003156. [CrossRef]

197. Shimoni, Y.; Friedlander, G.; Hetzroni, G.; Niv, G.; Altuvia, S.; Biham, O.; Margalit, H. Regulation of gene expression by small non-coding RNAs: A quantitative view. Mol. Syst. Biol. 2007, 3, 138. [CrossRef]

198. Levine, E.; Hwa, T. Small RNAs establish gene expression thresholds. Curr. Opin. Microbiol. 2008, 11, 574-579. [CrossRef]

199. Gottesman, S.; Storz, G. Bacterial Small RNA Regulators: Versatile Roles and Rapidly Evolving Variations. Cold Spring Harb. Perspect. Biol. 2011, 3. [CrossRef]

200. Bossi, L.; Figueroa-Bossi, N. Competing endogenous RNAs: A target-centric view of small RNA regulation in bacteria. Nat. Rev. Microbiol. 2016, 14, 775-784. [CrossRef]

201. Moon, K.; Gottesman, S. Competition among Hfq-binding small RNAs in Escherichia coli: Competition for Hfq in E. coli. Mol. Microbiol. 2011, 82, 1545-1562. [CrossRef] [PubMed]

202. Sorek, R.; Cossart, P. Prokaryotic transcriptomics: A new view on regulation, physiology and pathogenicity. Nat. Rev. Genet. 2010, 11, 9-16. [CrossRef] [PubMed]

203. Hör, J.; Gorski, S.A.; Vogel, J. Bacterial RNA Biology on a Genome Scale. Mol. Cell 2018, 70, 785-799. [CrossRef] [PubMed]

204. Georg, J.; Lalaouna, D.; Hou, S.; Lott, S.C.; Caldelari, I.; Marzi, S.; Hess, W.R.; Romby, P. The power of cooperation: Experimental and computational approaches in the functional characterization of bacterial sRNAs. Mol. Microbiol. 2020, 113, 603-612. [CrossRef]

205. Jagodnik, J.; Brosse, A.; Le Lam, T.N.; Chiaruttini, C.; Guillier, M. Mechanistic study of base-pairing small regulatory RNAs in bacteria. Methods 2017, 117, 67-76. [CrossRef] [PubMed]

206. Desgranges, E.; Caldelari, I.; Marzi, S.; Lalaouna, D. Navigation through the twists and turns of RNA sequencing technologies: Application to bacterial regulatory RNAs. Biochim. Biophys. Acta Gene Regul. Mech. 2020, 1863, 194506. [CrossRef]

207. Sharma, C.M.; Hoffmann, S.; Darfeuille, F.; Reignier, J.; Findeiss, S.; Sittka, A.; Chabas, S.; Reiche, K.; Hackermüller, J.; Reinhardt, R.; et al. The primary transcriptome of the major human pathogen Helicobacter pylori. Nature 2010, 464, 250-255. [CrossRef] 
208. Wurtzel, O.; Sapra, R.; Chen, F.; Zhu, Y.; Simmons, B.A.; Sorek, R. A single-base resolution map of an archaeal transcriptome. Genome Res. 2010, 20, 133-141. [CrossRef]

209. Dar, D.; Sorek, R. High-resolution RNA 3'-ends mapping of bacterial Rho-dependent transcripts. Nucleic Acids Res. 2018, 46, 6797-6805. [CrossRef]

210. Wurtzel, O.; Sesto, N.; Mellin, J.R.; Karunker, I.; Edelheit, S.; Bécavin, C.; Archambaud, C.; Cossart, P.; Sorek, R. Comparative transcriptomics of pathogenic and non-pathogenic Listeria species. Mol. Syst. Biol. 2012, 8, 583. [CrossRef]

211. Dar, D.; Shamir, M.; Mellin, J.R.; Koutero, M.; Stern-Ginossar, N.; Cossart, P.; Sorek, R. Term-seq reveals abundant ribo-regulation of antibiotics resistance in bacteria. Science 2016, 352, aad9822. [CrossRef] [PubMed]

212. Wurtzel, O.; Yoder-Himes, D.R.; Han, K.; Dandekar, A.A.; Edelheit, S.; Greenberg, E.P.; Sorek, R.; Lory, S. The single-nucleotide resolution transcriptome of Pseudomonas aeruginosa grown in body temperature. PLoS Pathog. 2012, 8, e1002945. [CrossRef] [PubMed]

213. Gómez-Lozano, M.; Marvig, R.L.; Molin, S.; Long, K.S. Genome-wide identification of novel small RNAs in Pseudomonas aeruginosa. Environ. Microbiol. 2012, 14, 2006-2016. [CrossRef] [PubMed]

214. Sahr, T.; Rusniok, C.; Dervins-Ravault, D.; Sismeiro, O.; Coppee, J.-Y.; Buchrieser, C. Deep sequencing defines the transcriptional map of L. pneumophila and identifies growth phase-dependent regulated ncRNAs implicated in virulence. RNA Biol. 2012, 9, 503-519. [CrossRef]

215. Wilms, I.; Overlöper, A.; Nowrousian, M.; Sharma, C.M.; Narberhaus, F. Deep sequencing uncovers numerous small RNAs on all four replicons of the plant pathogen Agrobacterium tumefaciens. RNA Biol. 2012, 9, 446-457. [CrossRef]

216. Miotto, P.; Forti, F.; Ambrosi, A.; Pellin, D.; Veiga, D.F.; Balazsi, G.; Gennaro, M.L.; Di Serio, C.; Ghisotti, D.; Cirillo, D.M. Genome-wide discovery of small RNAs in Mycobacterium tuberculosis. PLoS ONE 2012, 7, e51950. [CrossRef]

217. Dugar, G.; Herbig, A.; Förstner, K.U.; Heidrich, N.; Reinhardt, R.; Nieselt, K.; Sharma, C.M. High-resolution transcriptome maps reveal strain-specific regulatory features of multiple Campylobacter jejuni isolates. PLoS Genet. 2013, 9, e1003495. [CrossRef]

218. Dequivre, M.; Diel, B.; Villard, C.; Sismeiro, O.; Durot, M.; Coppée, J.Y.; Nesme, X.; Vial, L.; Hommais, F. Small RNA Deep-Sequencing Analyses Reveal a New Regulator of Virulence in Agrobacterium fabrum C58. Mol. Plant Microbe Interact. 2015, 28, 580-589. [CrossRef]

219. Rosinski-Chupin, I.; Sauvage, E.; Sismeiro, O.; Villain, A.; Da Cunha, V.; Caliot, M.-E.; Dillies, M.-A.; Trieu-Cuot, P.; Bouloc, P.; Lartigue, M.-F.; et al. Single nucleotide resolution RNA-seq uncovers new regulatory mechanisms in the opportunistic pathogen Streptococcus agalactiae. BMC Genomics 2015, 16, 419. [CrossRef]

220. Papenfort, K.; Förstner, K.U.; Cong, J.-P.; Sharma, C.M.; Bassler, B.L. Differential RNA-seq of Vibrio cholerae identifies the VqmR small RNA as a regulator of biofilm formation. Proc. Natl. Acad. Sci. USA 2015, 112, E766-E775. [CrossRef]

221. Carroll, R.K.; Weiss, A.; Broach, W.H.; Wiemels, R.E.; Mogen, A.B.; Rice, K.C.; Shaw, L.N. Genome-wide Annotation, Identification, and Global Transcriptomic Analysis of Regulatory or Small RNA Gene Expression in Staphylococcus aureus. mBio 2016, 7, e01990-01915. [CrossRef] [PubMed]

222. Heidrich, N.; Bauriedl, S.; Barquist, L.; Li, L.; Schoen, C.; Vogel, J. The primary transcriptome of Neisseria meningitidis and its interaction with the RNA chaperone Hfq. Nucleic Acids Res. 2017, 45, 6147-6167. [CrossRef] [PubMed]

223. Zhukova, A.; Fernandes, L.G.; Hugon, P.; Pappas, C.J.; Sismeiro, O.; Coppée, J.-Y.; Becavin, C.; Malabat, C.; Eshghi, A.; Zhang, J.-J.; et al. Genome-Wide Transcriptional Start Site Mapping and sRNA Identification in the Pathogen Leptospira interrogans. Front. Cell. Infect. Microbiol. 2017, 7, 10. [CrossRef] [PubMed]

224. Kröger, C.; MacKenzie, K.D.; Alshabib, E.Y.; Kirzinger, M.W.B.; Suchan, D.M.; Chao, T.-C.; Akulova, V.; Miranda-CasoLuengo, A.A.; Monzon, V.A.; Conway, T.; et al. The primary transcriptome, small RNAs and regulation of antimicrobial resistance in Acinetobacter baumannii ATCC 17978. Nucleic Acids Res. 2018, 46, 9684-9698. [CrossRef]

225. Rosinski-Chupin, I.; Sauvage, E.; Fouet, A.; Poyart, C.; Glaser, P. Conserved and specific features of Streptococcus pyogenes and Streptococcus agalactiae transcriptional landscapes. BMC Genomics 2019, 20, 236. [CrossRef] [PubMed]

226. Sinha, D.; Zimmer, K.; Cameron, T.A.; Rusch, D.B.; Winkler, M.E.; De Lay, N.R. Redefining the Small Regulatory RNA Transcriptome in Streptococcus pneumoniae Serotype 2 Strain D39. J. Bacteriol. 2019, 201. [CrossRef] 
227. Lécrivain, A.-L.; Beckmann, B.M. Bacterial RNA in extracellular vesicles: A new regulator of host-pathogen interactions? Biochim. Biophys. Acta Gene Regul. Mech. 2020, 1863, 194519. [CrossRef]

228. Koeppen, K.; Hampton, T.H.; Jarek, M.; Scharfe, M.; Gerber, S.A.; Mielcarz, D.W.; Demers, E.G.; Dolben, E.L.; Hammond, J.H.; Hogan, D.A.; et al. A Novel Mechanism of Host-Pathogen Interaction through sRNA in Bacterial Outer Membrane Vesicles. PLoS Pathog. 2016, 12, e1005672. [CrossRef]

229. Riedel, C.U.; Monk, I.R.; Casey, P.G.; Waidmann, M.S.; Gahan, C.G.M.; Hill, C. AgrD-dependent quorum sensing affects biofilm formation, invasion, virulence and global gene expression profiles in Listeria monocytogenes. Mol. Microbiol. 2009, 71, 1177-1189. [CrossRef]

230. Woodson, S.A.; Panja, S.; Santiago-Frangos, A. Proteins That Chaperone RNA Regulation. Microbiol. Spectr. 2018, 6. [CrossRef]

231. Trinquier, A.; Durand, S.; Braun, F.; Condon, C. Regulation of RNA processing and degradation in bacteria. Biochim. Biophys. Acta Gene Regul. Mech. 2020, 1863, 194505. [CrossRef] [PubMed]

232. Romeo, T.; Babitzke, P. Global Regulation by CsrA and Its RNA Antagonists. Microbiol. Spectr. 2018, 6. [CrossRef]

233. Pichon, C.; du Merle, L.; Caliot, M.E.; Trieu-Cuot, P.; Le Bouguénec, C. An in silico model for identification of small RNAs in whole bacterial genomes: Characterization of antisense RNAs in pathogenic Escherichia coli and Streptococcus agalactiae strains. Nucleic Acids Res. 2012, 40, 2846-2861. [CrossRef] [PubMed]

234. Pain, A.; Ott, A.; Amine, H.; Rochat, T.; Bouloc, P.; Gautheret, D. An assessment of bacterial small RNA target prediction programs. RNA Biol. 2015, 12, 509-513. [CrossRef] [PubMed]

235. Wright, P.R.; Mann, M.; Backofen, R. Structure and Interaction Prediction in Prokaryotic RNA Biology. Microbiol. Spectr. 2018, 6. [CrossRef]

236. Lalaouna, D.; Carrier, M.-C.; Semsey, S.; Brouard, J.-S.; Wang, J.; Wade, J.T.; Massé, E. A 3' external transcribed spacer in a tRNA transcript acts as a sponge for small RNAs to prevent transcriptional noise. Mol. Cell. 2015, 58, 393-405. [CrossRef]

237. Lalaouna, D.; Prévost, K.; Eyraud, A.; Massé, E. Identification of unknown RNA partners using MAPS. Methods 2017, 117, 28-34. [CrossRef]

238. Melamed, S.; Faigenbaum-Romm, R.; Peer, A.; Reiss, N.; Shechter, O.; Bar, A.; Altuvia, Y.; Argaman, L.; Margalit, H. Mapping the small RNA interactome in bacteria using RIL-seq. Nat. Protoc. 2018, 13, 1-33. [CrossRef]

239. Waters, S.A.; McAteer, S.P.; Kudla, G.; Pang, I.; Deshpande, N.P.; Amos, T.G.; Leong, K.W.; Wilkins, M.R.; Strugnell, R.; Gally, D.L.; et al. Small RNA interactome of pathogenic E. coli revealed through crosslinking of RNase E. EMBO J. 2017, 36, 374-387. [CrossRef]

240. Okumura, K.; Ohtani, K.; Hayashi, H.; Shimizu, T. Characterization of genes regulated directly by the VirR/VirS system in Clostridium perfringens. J. Bacteriol. 2008, 190, 7719-7727. [CrossRef]

241. Wade, J.T. Mapping Transcription Regulatory Networks with ChIP-seq and RNA-seq. Adv. Exp. Med. Biol. 2015, 883, 119-134. [CrossRef]

242. Mann, B.; van Opijnen, T.; Wang, J.; Obert, C.; Wang, Y.-D.; Carter, R.; McGoldrick, D.J.; Ridout, G.; Camilli, A.; Tuomanen, E.I.; et al. Control of virulence by small RNAs in Streptococcus pneumoniae. PLoS Pathog. 2012, 8, e1002788. [CrossRef]

243. Klemm, E.J.; Wong, V.K.; Dougan, G. Emergence of dominant multidrug-resistant bacterial clades: Lessons from history and whole-genome sequencing. Proc. Natl. Acad. Sci. USA 2018, 115, 12872-12877. [CrossRef] [PubMed]

244. Peacock, S.J.; Paterson, G.K. Mechanisms of Methicillin Resistance in Staphylococcus aureus. Annu. Rev. Biochem. 2015, 84, 577-601. [CrossRef] [PubMed]

245. Durack, J.; Lynch, S.V. The gut microbiome: Relationships with disease and opportunities for therapy. J. Exp. Med. 2019, 216, 20-40. [CrossRef] [PubMed]

246. Lerminiaux, N.A.; Cameron, A.D.S. Horizontal transfer of antibiotic resistance genes in clinical environments. Can. J. Microbiol. 2019, 65, 34-44. [CrossRef]

247. McInnes, R.S.; McCallum, G.E.; Lamberte, L.E.; van Schaik, W. Horizontal transfer of antibiotic resistance genes in the human gut microbiome. Curr. Opin. Microbiol. 2020, 53, 35-43. [CrossRef]

248. Tiwari, S.; Jamal, S.B.; Hassan, S.S.; Carvalho, P.V.S.D.; Almeida, S.; Barh, D.; Ghosh, P.; Silva, A.; Castro, T.L.P.; Azevedo, V. Two-Component Signal Transduction Systems of Pathogenic Bacteria As Targets for Antimicrobial Therapy: An Overview. Front. Microbiol. 2017, 8, 1878. [CrossRef] 
249. Bem, A.E.; Velikova, N.; Pellicer, M.T.; van Baarlen, P.; Marina, A.; Wells, J.M. Bacterial Histidine Kinases as Novel Antibacterial Drug Targets. ACS Chem. Biol. 2015, 10, 213-224. [CrossRef]

250. Rasko, D.A.; Moreira, C.G.; Li, D.R.; Reading, N.C.; Ritchie, J.M.; Waldor, M.K.; Williams, N.; Taussig, R.; Wei, S.; Roth, M.; et al. Targeting QseC Signaling and Virulence for Antibiotic Development. Science 2008, 321, 1078-1080. [CrossRef]

251. Barra, M.; Danino, T.; Garrido, D. Engineered Probiotics for Detection and Treatment of Inflammatory Intestinal Diseases. Front. Bioeng. Biotechnol. 2020, 8. [CrossRef] [PubMed]

252. Zhou, Z.; Chen, X.; Sheng, H.; Shen, X.; Sun, X.; Yan, Y.; Wang, J.; Yuan, Q. Engineering probiotics as living diagnostics and therapeutics for improving human health. Microb. Cell Fact. 2020, 19, 56. [CrossRef] [PubMed]

253. Palmer, J.D.; Piattelli, E.; McCormick, B.A.; Silby, M.W.; Brigham, C.J.; Bucci, V. Engineered Probiotic for the Inhibition of Salmonella via Tetrathionate-Induced Production of Microcin H47. ACS Infect. Dis. 2018, 4, 39-45. [CrossRef] [PubMed]

254. Crooke, S.T.; Witztum, J.L.; Bennett, C.F.; Baker, B.F. RNA-Targeted Therapeutics. Cell Metab. 2018, 27, 714-739. [CrossRef] [PubMed]

255. Sully, E.K.; Geller, B.L. Antisense antimicrobial therapeutics. Curr. Opin. Microbiol. 2016, 33, 47-55. [CrossRef]

256. Sawyer, A.J.; Wesolowski, D.; Gandotra, N.; Stojadinovic, A.; Izadjoo, M.; Altman, S.; Kyriakides, T.R. A peptide-morpholino oligomer conjugate targeting Staphylococcus aureus gyrA mRNA improves healing in an infected mouse cutaneous wound model. Int. J. Pharm. 2013, 453, 651-655. [CrossRef]

257. Law, C.O.K.; Huang, C.; Pan, Q.; Lee, J.; Hao, Q.; Chan, T.-F.; Lo, N.W.S.; Ang, I.L.; Koon, A.; Ip, M.; et al. A Small RNA Transforms the Multidrug Resistance of Pseudomonas aeruginosa to Drug Susceptibility. Mol. Ther. Nucleic Acids 2019, 16, 218-228. [CrossRef]

258. Xue, X.-Y.; Mao, X.-G.; Zhou, Y.; Chen, Z.; Hu, Y.; Hou, Z.; Li, M.-K.; Meng, J.-R.; Luo, X.-X. Advances in the delivery of antisense oligonucleotides for combating bacterial infectious diseases. Nanomed. Nanotechnol. Biol. Med. 2018, 14, 745-758. [CrossRef]

259. Vogel, J. An RNA biology perspective on species-specific programmable RNA antibiotics. Mol. Microbiol. 2020, 113, 550-559. [CrossRef]

260. Dersch, P.; Khan, M.A.; Mühlen, S.; Görke, B. Roles of Regulatory RNAs for Antibiotic Resistance in Bacteria and Their Potential Value as Novel Drug Targets. Front. Microbiol. 2017, 8. [CrossRef] [PubMed]

261. Petchiappan, A.; Chatterji, D. Antibiotic Resistance: Current Perspectives. ACS Omega 2017, 2, 7400-7409. [CrossRef] [PubMed]

262. El-Mowafi, S.A.; Alumasa, J.N.; Ades, S.E.; Keiler, K.C. Cell-based assay to identify inhibitors of the Hfq-sRNA regulatory pathway. Antimicrob. Agents Chemother. 2014, 58, 5500-5509. [CrossRef]

263. Bikard, D.; Barrangou, R. Using CRISPR-Cas systems as antimicrobials. Curr. Opin. Microbiol. 2017, 37, 155-160. [CrossRef] [PubMed]

264. Mion, S.; Rémy, B.; Plener, L.; Brégeon, F.; Chabrière, E.; Daudé, D. Quorum Quenching Lactonase Strengthens Bacteriophage and Antibiotic Arsenal Against Pseudomonas aeruginosa Clinical Isolates. Front. Microbiol. 2019, 10. [CrossRef] [PubMed]

265. Blount, K.F.; Breaker, R.R. Riboswitches as antibacterial drug targets. Nat. Biotechnol. 2006, 24, 1558-1564. [CrossRef]

266. Lünse, C.E.; Schüller, A.; Mayer, G. The promise of riboswitches as potential antibacterial drug targets. Int. J. Med. Microbiol. 2014, 304, 79-92. [CrossRef] [PubMed]

267. Peltier, J.; Soutourina, O. Identification of c-di-GMP-Responsive Riboswitches. In c-di-GMP Signaling; Sauer, K., Ed.; Methods in Molecular Biology; Springer: New York, NY, USA, 2017; pp. 377-402. ISBN 978-1-4939-7239-5.

268. McKee, R.W.; Harvest, C.K.; Tamayo, R. Cyclic Diguanylate Regulates Virulence Factor Genes via Multiple Riboswitches in Clostridium difficile. mSphere 2018, 3. [CrossRef]

269. Yan, L.-H.; Le Roux, A.; Boyapelly, K.; Lamontagne, A.-M.; Archambault, M.-A.; Picard-Jean, F.; Lalonde-Seguin, D.; St-Pierre, E.; Najmanovich, R.J.; Fortier, L.-C.; et al. Purine analogs targeting the guanine riboswitch as potential antibiotics against Clostridioides difficile. Eur. J. Med. Chem. 2018, 143, 755-768. [CrossRef] [PubMed]

270. Mulhbacher, J.; Brouillette, E.; Allard, M.; Fortier, L.-C.; Malouin, F.; Lafontaine, D.A. Novel riboswitch ligand analogs as selective inhibitors of guanine-related metabolic pathways. PLoS Pathog. 2010, 6, e1000865. [CrossRef] 
271. Ster, C.; Allard, M.; Boulanger, S.; Lamontagne Boulet, M.; Mulhbacher, J.; Lafontaine, D.A.; Marsault, E.; Lacasse, P.; Malouin, F. Experimental treatment of Staphylococcus aureus bovine intramammary infection using a guanine riboswitch ligand analog. J. Dairy Sci. 2013, 96, 1000-1008. [CrossRef]

272. Blount, K.F.; Megyola, C.; Plummer, M.; Osterman, D.; O’Connell, T.; Aristoff, P.; Quinn, C.; Chrusciel, R.A.; Poel, T.J.; Schostarez, H.J.; et al. Novel riboswitch-binding flavin analog that protects mice against Clostridium difficile infection without inhibiting cecal flora. Antimicrob. Agents Chemother. 2015, 59, 5736-5746. [CrossRef] [PubMed]

Publisher's Note: MDPI stays neutral with regard to jurisdictional claims in published maps and institutional affiliations.

(C) 2020 by the authors. Licensee MDPI, Basel, Switzerland. This article is an open access article distributed under the terms and conditions of the Creative Commons Attribution (CC BY) license (http://creativecommons.org/licenses/by/4.0/). 